\title{
Geopolitical species revisited: genomic and morphological data indicate that the roundtail chub Gila robusta species complex (Teleostei, Cyprinidae) is a single species
}

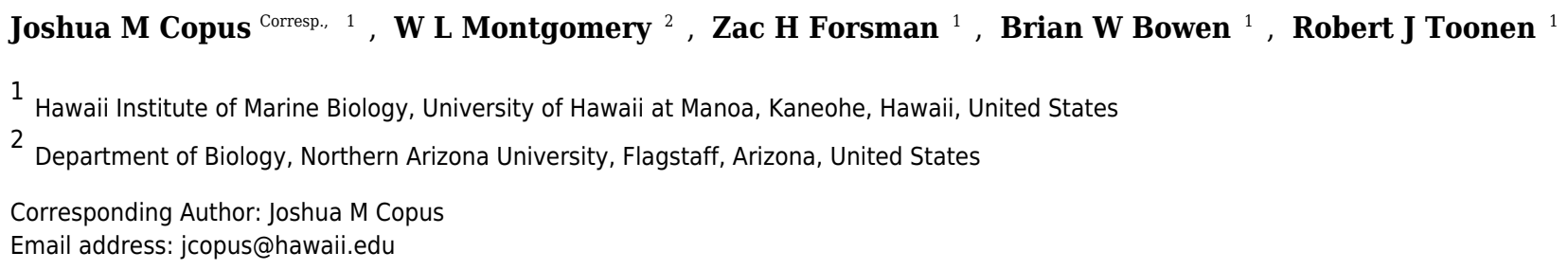

The Gila robusta species complex in the Lower Colorado River Basin has a complicated taxonomic history. Recent authors have separated this group into three nominal taxa, $G$. robusta, $G$. intermedia, and G. nigra, however aside from location, no reliable method of distinguishing individuals of these species currently exists. To assess relationships within this group, we examined morphology of type specimens and fresh material, and used RADseq methods to assess phylogenetic relationship among these nominal species. Maximum likelihood and Bayesian inference tree building methods reveal high concordance between tree topologies based on the mitochondrial and nuclear datasets. Coalescent SNAPP analysis resolved a similar tree topology. Neither morphological nor molecular data reveal diagnostic differences between these species as currently defined. As such, $G$. intermedia and $G$. nigra should be considered synonyms of the senior $G$. robusta. We hypothesize that climate driven wet and dry cycles have led to periodic isolation of population subunits and subsequent local divergence followed by reestablished connectivity and mixing. Management plans should therefore focus on retaining genetic variability and viability of geographic populations to preserve adaptability to changing climate conditions. 
2

3 Geopolitical species revisited: genomic and morphological data indicate that the roundtail chub

4 Gila robusta species complex (Teleostei, Cyprinidae) is a single species

5

6 Joshua M. Copus ${ }^{1}$, W.L. Montgomery ${ }^{2}$, Zac H. Forsman ${ }^{1}$, Brian W. Bowen ${ }^{1}$, Robert J. Toonen ${ }^{1}$

7

8

9 'Hawai'i Institute of Marine Biology, University of Hawai ‘i at Mānoa, Kāne ‘ohe, HI 96744, 10 USA

11 2Department of Biology, Northern Arizona University, Flagstaff, AZ 86011, USA

12

13 *Corresponding author: Joshua M. Copus, joshua.copus@gmail.com

14

15

16

17 


\section{Abstract}

20 The Gila robusta species complex in the Lower Colorado River Basin has a complicated

21 taxonomic history. Recent authors have separated this group into three nominal taxa, G. robusta,

22 G. intermedia, and G. nigra, however aside from location, no reliable method of distinguishing

23 individuals of these species currently exists. To assess relationships within this group, we

24 examined morphology of type specimens and fresh material, and used RADseq methods to

25 assess phylogenetic relationship among these nominal species. Maximum likelihood and

26 Bayesian inference tree building methods reveal high concordance between tree topologies based

27 on the mitochondrial and nuclear datasets. Coalescent SNAPP analysis resolved a similar tree

28 topology. Neither morphological nor molecular data reveal diagnostic differences between these

29 species as currently defined. As such, G. intermedia and G. nigra should be considered

30 synonyms of the senior G. robusta. We hypothesize that climate driven wet and dry cycles have

31 led to periodic isolation of population subunits and subsequent local divergence followed by

32 reestablished connectivity and mixing. Management plans should therefore focus on retaining

33 genetic variability and viability of geographic populations to preserve adaptability to changing

34 climate conditions.

35

36

37

38

39

40 


\section{Introduction}

43

44

45

46

47

48

49

50

51

52

53

54

55

56

57

58

59

60

61

62

63

64

65

66

67

68

69

70

71

The fish genus Gila Baird \& Girard 1853 contains 20 currently recognized species in the Western United States and Mexico. Of these, G. cypha Miller 1946, G. elegans Baird \& Girard 1853, G. intermedia (Girard 1856), G. jordani Tanner 1950, G. nigra Cope 1875, G. robusta Baird \& Girard 1853, and G. seminuda Cope \& Yarrow 1875 inhabit the Colorado River Basin and make up the Gila robusta species complex (Gerber, Tibbets \& Dowling, 2001). The Lower Colorado River Basin, separated from the Upper Colorado River Basin by Glen Canyon Dam, is occupied by G. robusta, G. intermedia, and G. nigra. These Gila populations, as with many freshwater fishes within the Lower Colorado River Drainage are in decline from anthropogenic threats such as habitat destruction and modification accompanying human population growth and interactions with non-native fishes (Minckley \& Marsh, 2009). These declines led to the listing of $G$. intermedia as endangered under the U.S. Endangered Species Act (USFWS, 2005) and a proposal for G. robusta and G. nigra to be listed as threatened (USFWS, 2015).

Over the past 150 years, the G. robusta complex within the Lower Colorado River Basin has received considerable attention in an attempt to resolve relationships among the populations that inhabit these drainages. Hypotheses such as ecophenotypic plasticity, introgression, and cryptic speciation have all been invoked to account for geographic variation in genetic structure, as well as morphological and ecological traits within and among species of Gila (e.g. Miller, 1946; Dowling \& Demarias, 1993; Gerber, Tibbets \& Dowling, 2001; Marsh, Clarkson \& Dowling, 2017). Numerous molecular studies have attempted to resolve the relationships of the Gila robusta complex. Although interpretations of the data vary, there is no clear evidence to date that the three nominal species of Gila in the drainages of the Lower Colorado River basin represent reproductively isolated and distinct evolutionary units (Demarias, 1992; Demarias et al., 1992; Dowling \& Demarias, 1993; Schonhuth et al., 2012; Schonhuth et al., 2014; Dowling et al., 2015; Marsh, Clarkson \& Dowling, 2017), nor has a reliable method (morphological or molecular) of assigning individual fish to species been identified (Moran et al., 2017; Carter et al., 2018). The current practice of species identification for managers and researchers working with the G. robusta complex requires identifications based on collection locality as determined by Rinne (1969) and later revised by Minckley \& Demarias (2000) based on mean morphological differences of populations rather than diagnosable morphological or molecular 
72 characters of individuals, because no such characters have been identified. The Gila populations

73 within these localities were assigned to distinct species (G. robusta and G. intermedia) and

74 subspecies (G. grahamii [=nigra]; Rinne, 1969; Rinne, 1976) based on mean morphological

75 differences among populations. Rinne interpreted these mean differences to represent distinct

76 taxonomic units (species and subspecies) but dismissed the variance in morphology that exists

77 within each population. Minckley \& Demarias (2000) revised the geographic ranges and

78 taxonomic status of this group and developed a taxonomic key for the identification of the three

79 species. Unfortunately, the implementation of this key has been problematic for managers and

80 researchers attempting to assign species names to individual fish, in part due to the reliance on

81 population means as diagnostic characters, and in part due to confusion arising from variation

82 among individuals within and among locations.

83 A recent review of the specific status of Gila intermedia and Gila nigra as distinct from

84 Gila robusta was undertaken by the American Society of Ichthyologists and Herptologists -

85 American Fisheries Society (ASIH-AFS) Committee on the Names of Fishes. Upon reviewing

86 all available literature and data, including much of the data presented here, and hosting a

87 symposium on the topic, the committee concluded that there was no evidence that Gila

88 intermedia and Gila nigra were distinct from G. robusta (Page et al., 2017). Since this decision

89 from the ASIH-AFS, the USFWS has withdrawn their proposal to list G. robusta and G. nigra as

90 threatened under the Endangered Species Act until a species status assessment of the newly

91 defined G. robusta taxon can be undertaken.

92 Here we review the systematic and taxonomic history of this group to provide a

93 foundation for evaluating the nomenclature within the G. robusta complex. We provide a

94 comprehensive morphological comparison of the type series of each species, as well as fresh

95 material from streams throughout the Lower Colorado River Basin, to test for diagnostic

96 characters. Finally, we use molecular phylogenomics to ascertain the evolutionary relationships

97 among populations and putative species.

99 Systematic and taxonomic review

100 There has been considerable confusion regarding the systematics and taxonomy of the

101 Gila robusta complex within the Lower Colorado River Basin, largely due to a complex array of

102 phenotypes (Demarias et al., 1992). Many species within the genus Gila Baird \& Girard 1853 
103 have been described multiple times and the G. robusta complex of the Lower Colorado River

104 Basin is no exception. We identified fifteen specific names and seven generic names applied to 105 these fishes.

106

107

G. robusta Baird \& Girard 1853

108

Gila robusta Baird \& Girard 1853 is the type species for the genus. The type series of the

109 species is cataloged as USNM 246, but a note included with the type specimens states, "These, the types of Gila robusta B.+G., are cat. No. 246. They were reentered by error as 47983 and attributed to nos. $276+273$, which are cods! Nos. $276+277$ were attributed as type nos. of this species, by error, by Jordan \& Evermann 1896:227. R.R. Miller III: 1945” (Figure S1). This is one of a number of clerical errors uncovered in the taxonomic history of this fish and is indicative of the historic pattern of confusion surrounding the systematics of this complex. River, New Mexico, but Smith, Miller \& Sable (1979) suggest that this locality is a clerical error, based on the argument that the Zuni River was unsuitable habitat for G. robusta during the time at which the type specimens were collected (1851). Smith, Miller \& Sable (1979) suggested that the specimens were actually from another collection site of the Sitgreaves expedition, the Little

120 Colorado River, below Grand Falls, Coconino County, Arizona. Sublette, Hatch \& Sublette 121 (1990) dispute the assertions of Smith, Miller \& Sable (1979), and contend that the syntypes 122 were collected from the Zuni River in 1851, and note that additional specimens were 123 subsequently collected twice in 1873 and once in 1879 on the Zuni River by different collectors.

124 It is highly unlikely that multiple clerical errors on different expeditions would have occurred at 125 this locality with this species. Sublette, Hatch \& Sublette (1990) suggest that the Zuni River 126 represented marginal habitat that may have received recruits from the Rio Pescado and that they 127 have since been extirpated from the Zuni River. The journal of SW Woodhouse, the naturalist 128 who originally collected these fishes, clearly states that on Saturday the 6th of September 1851, 129 he received these fishes while camped at the Zuni Pueblo, which were "collected from the 130 creek." The argument that the syntypes were collected on the Little Colorado River rather than 131 the Zuni is therefore dubious and we maintain the type locality as the Zuni River for G. robusta. 132 
134 Girard (1856) described Tigoma intermedia from specimens collected on the Rio San

135 Pedro in Arizona and noted that it was morphologically intermediate between T. pulchella (Baird

$136 \&$ Girard 1854) and T. purpurea Girard 1856 (both of which are now regarded as valid species

137 within the genus Gila). Evermann \& Rutter (1895) placed T. intermedia within the genus

138 Leuciscus Cuvier 1816. Jordan \& Evermann (1896) synonymized Tigoma and Richardsonius

139 Girard 1856 with Leuciscus, and suggested that L. intermedius and L. niger (Cope 1875) (now

140 Gila nigra Cope 1875) may be conspecific. Fowler (1924) retained this genus placement for $L$.

141 intermedius. Snyder (1914) regarded T. intermedia and G. nigra as synonyms of Gila gibbosa

142 Baird \& Girard 1854, which he placed within the genus Richardsonius Girard 1856. Jordan \&

143 Gilbert (1883) asserted that gibbosus Baird \& Girard 1854 was unavailable due to homonymy

144 resulting from placement of Leuciscus gibbosus Ayres 1854 and Gila gibbosa Baird \& Girard

1451854 within the genus Squalius Bonaparte 1837 (Gila gibbosa Baird \& Girard 1854 being the

146 junior homonym). Jordan \& Evermann (1896) placed both of these species within the genus

147 Leuciscus Cuvier 1816, creating another case of homonymy, this time within Leuciscus. In both

148 cases, gibbosus Ayres 1854 was identified as the senior homonym; however, that name was itself

149 preoccupied by Leuciscus between gibbosus Storer 1845 and gibbosus Ayres 1854. In any case,

150 G. gibbosa Baird \& Girard 1854 is not an available name. Miller (1945) treated intermedia as a

151 subspecies of G. robusta Baird \& Girard 1853, which was followed by subsequent authors (e.g.

152 Miller, 1946; Uyeno, 1961; Miller, 1961; LaRivers, 1962; Sigler \& Miller, 1963; Miller \& Lowe,

153 1964; Uyeno \& Miller, 1965; Barber \& Minckley, 1966; Miller \& Lowe, 1967; Cole, 1968;

154 Minckley \& Alger, 1968; Minckley, 1969; Lee, 1980; Robins, Bailey \& Bond,1980).

155 Rinne (1969) recognized two distinct species within the Lower Colorado River Basin: $G$.

156 robusta for the more broadly distributed form, and G. intermedia for populations principally

157 distributed in central and southern Arizona. Within the synonymy of G. intermedia, he also

158 included G. gibbosus, G. nigra, and G. lemmoni, noting that the former was unavailable due to

159 homonymy, thereby asserting G. intermedia as the next available name. Rinne (1969) does not

160 appear to have examined any of the type series of G. intermedia, but states "in all respects, they

161 [populations he labels as G. intermedia] correspond to the original description of Tigoma (=Gila)

162 intermedia Girard 1856". The original description of G. intermedia (Girard 1856) consisted of

163 the following text: "Intermediate between T. pulchella and T. purpurea, more closely related

164 however to the former than to the latter. The fins are much less developed, the inferior fins 
165 especially are quite small." The original description did not include enough diagnostic characters

166 to confidently conclude that the populations Rinne (1969) defines as G. intermedia are

167 conspecific with the type specimens of $G$. intermedia, and there is no evidence that Rinne

168 examined either pulchella or purpurea before asserting that G. intermedia was in fact, the correct

169 name for these populations. Nevertheless, most subsequent authors followed Rinne (1969) in

170 treating G. intermedia as a valid species (e.g. Stout, Bloom \& Glass,1970; Minckley, 1971;

171 1973; Rinne, 1976; Hocutt \& Wiley, 1986; Minckley, Hendrickson \& Bond, 1986; Sublette,

172 Hatch \& Sublette, 1990; Robins et al., 1991; Winfield \& Nelson, 1991; Espinosa-Pérez, Gaspar-

173 Dallanes \& Fuentes-Mata,1993; Gilbert, 1998; Minckley \& DeMarias, 2000; Norris, Fischer \&

174 Minckley, 2003; Nelson et al., 2004; Scharpf, 2005; Miller, 2005; Minckley \& Marsh, 2009;

175 Page \& Burr, 2011; Page et al., 2013), despite the known complex taxonomic history and a lack

176 of any discrete identifying characteristics.

177

178 G. grahamii Baird \& Girard 1853

179 Although Gila grahamii is currently recognized as a synonym of G. robusta, due to the

180 complicated systematic history of this group, particularly with respect to G. nigra, we include

181 this nomenclatural account to promote clarity. Baird \& Girard (1853) described Gila grahamii

182 (often misspelled in the literature as grahami) from specimens collected in the Rio San Pedro,

183 Gila River basin. Günther (1868) placed it within the genus Leuciscus Cuvier 1816. Cope \&

184 Yarrow (1875) placed the species back in the genus Gila and recognized it as distinct from both

185 G. robusta Baird \& Girard 1853 and G. nigra Cope 1875. Evermann \& Rutter (1895) treated G.

186 grahamii as a synonym of G. robusta, and subsequent early authors followed this assignment.

187 This synonymy remained stable until Rinne (1969), who regarded grahamii as a subspecies of $G$.

188 robusta, recognized populations collected from the tributaries of the Verde River and the upper

189 Gila River system as distinct from the subspecies G. r. robusta in the main stem Verde and Gila

190 Rivers. Rinne (1969) recognized current San Pedro populations (type locality of G. grahamii) as

191 belonging to the species he referred to as G. intermedia, even though he accepted G. r. grahamii

192 for his "headwater" form (again, apparently without examining type specimens). In the years

193 between 1969 and 2000, there was not consistent recognition of G. r. grahamii as a valid

194 subspecies, but no authors treated it as a valid species, or as a synonym or subspecies of any

195 species other than G. robusta (e.g., Rinne, 1976; Lee et al., 1980; Robins, 1980; Holden \& 
196 Minckley, 1980; Mayden, 1992; La Rivers, 1994; Gilbert, 1998). Minckley \& Demarias (2000)

197 regarded the populations referred to by Rinne (1969) as G. r. grahamii as representing a distinct

198 species, even though they noted that it is likely of hybrid origin and paraphyletic. However, they

199 also noted that the syntypes of $G$. grahamii belong to what Rinne (1969) regarded as the

200 subspecies G. r. robusta (citing pers comm RR Miller \& WL Minckley). Therefore, they

201 recognized G. nigra Cope 1875, as the earliest available name for the species previously referred

202 to by Rinne (1969) as G. r. grahamii.

203

204

G. nigra Cope 1875

205

206

G. nigra Cope in Cope \& Yarrow1875 was described from specimens collected in Ash

207

Creek and at San Carlos, Arizona. Jordan \& Gilbert 1883 placed it in the genus Squalius

208

Bonaparte 1837, and later Jordan \& Evermann (1896) placed it in the genus Leuciscus. They also

209

regarded Gila gibbosa Baird \& Girard 1854 as conspecific, but unavailable due to homonymy

210 (see above). Gilbert \& Scofield (1898) synonymized G. nigra with T. intermedia, which they placed in the genus Leuciscus. Snyder (1915) regarded G. niger as a synonym of G. gibbosa (within the genus Richardsonius), failing to recognize that the latter species name was not available due to homonymy. Fowler (1924) followed Gilbert \& Scofield (1898) in treating $G$. nigra as a synonym of intermedius, within the genus Leuciscus. Subsequent treatments placed nigra in synonymy with intermedia (see above). This synonymy was broadly followed until Minckley \& Demarias (2000) recognized G. nigra as the earliest available name to refer to the species treated by Rinne (1969) as G. r. grahamii.

Synonymies now considered valid

Along with the considerable synonymy of Gila robusta are species that were at one time considered synonyms of G. robusta and are now considered valid. Gila elegans Baird \& Girard 1853 was treated as a synonym of G. robusta by Ellis (1914) and as a subspecies by Miller (1945) and La Rivers (1994). However, G. elegans was treated as valid by Vanicek (1967) and subsequent authors. Gila jordani Tanner 1950 was treated as a subspecies of G. robusta by Rinne (1976), Lee (1980), La Rivers (1994), and Gilbert (1998) but was recognized as valid by Minckley \& Marsh (2009) and subsequent authors. Clinostomus pandora Cope 1872 was treated as a synonym of G. robusta by Ellis (1914) but valid as Gila pandora (Cope 1872) by 
227 subsequent authors. Tigoma egregia Girard 1858 was treated as a synonym of G. robusta by

228 Ellis (1914) but regarded as valid as Richardsonius Girard 1856 egregius (Girard 1858) by

229 subsequent authors. Finally, Gila seminuda Cope \& Yarrow 1875 was treated as a subspecies of

230 G. robusta by Ellis (1914), Snyder (1915), Rinne (1976), and Lee (1980) but regarded as valid

231 by Gilbert (1998) and subsequent authors.

232

\section{Materials and Methods}

234 Type material for each of the currently recognized species of the G. robusta complex as 235 well as the type of the G. robusta synonym G. grahamii were obtained from the Smithsonian 236 National Museum of Natural History (G. robusta (USNM 246, N=2), G. nigra (USNM 16972, $237 \mathrm{~N}=3 ; 16987 \mathrm{~N}=2)$, G. intermedia (USNM 232, N=4), and G. grahamii (USNM 253, N=1).

Due to the problems associated with the taxonomic key (Moran et al., 2017; Carter et al., 2018) the current practice of species identification for managers and researchers working with the G. robusta complex within the Lower Colorado River Basin is based on drainage location, as assigned by Rinne (1969) and later revised by Minckley and Demarias (2000). We follow this convention because no alternative method of assignment is currently available. Morphological and molecular analysis of fresh specimens of each nominal species ( $G$. robusta $\mathrm{N}=6, G$. intermedia $\mathrm{N}=6$, and $G$. nigra $\mathrm{N}=5)$ as well as $G$. elegans $(\mathrm{N}=1)$ and $G$. cypha $(\mathrm{N}=1)$ as outgroups were analyzed from streams throughout their range, with the exception of O'Donnell Canyon material collected from the captive population held at the International Wildlife Museum, and Eagle Creek and Verde River samples collected from the Bubbling Ponds Fish Hatchery. One individual per location across the range of each species was analyzed to capture as much within species variation as possible (Figure 1) Tissue of G. elegans and G. cypha were obtained from the Arizona Game and Fish Department Bubbling Ponds fish hatchery. Tissue samples were stored in both salt-saturated DMSO solution $(20 \%$ dimethyl sulfoxide, $0.25 \mathrm{M}$ EDTA, pH 8.0, saturated with NaCl; Seutin, White, \& Boag, 1991; Gaither et al., 2011) and RNA Later (ThermoFisher Scientific, Waltham, MA) for reduced representation genomic sequencing using the ezRAD protocol (Toonen et al., 2013; Knapp et al., 2016). Specimens were 255 frozen prior to morphological analyses. 
257 Morphological Analysis: Fresh specimens were thawed and radiographed to aid in morphological

258 analysis. Species names were assigned to fresh specimens based on sampling location as

259 designated by Rinne (1969) and Minckley and Demarias (2000) (see above). Meristic and

260 morphometric analysis follow methods outlined in Hubbs \& Lagler (1958). All statistical

261 comparisons of morphology were implemented in R (R Core Team, 2016). Linear regression was

262 performed on each of the morphometric characters to test for allometric growth and confirm that

263 each of these characters scale linearly with size. Variables were then standardized by length for

264 comparison. F-tests (to determine equal or unequal variance) and t-tests were performed on all

265 standardized variables to test whether shrinkage due to preservation causes significant

266 differences between type material and fresh material for any variable. We find that allometric

267 growth and shrinkage from preservation are not significant between fresh and preserved

268 specimens and consequently comparisons between size and preservation method were possible

269 (Table S1). Morphometric measurements are presented as a percentage of standard length, head

270 length, or body depth.

271

272 Reduced Representation Genomic Data Production: Genomic DNA was extracted from tissue

273 using the Omega E.Z.N.A Tissue DNA Kit (Omega Biotek, Norcross, GA) following the

274 manufacturer's protocol except that HPLC grade $\mathrm{H}_{2} \mathrm{O}$ was substituted for the elution buffer.

275 DNA aliquots were visualized following electrophoresis on a 1\% agarose gel to assess quantity

276 and quality. For extractions that did not yield $>1 \mu \mathrm{g}$ high molecular weight DNA (>10kb),

277 multiple extractions from the same individual were completed and extractions were pooled and

278 concentrated using an Eppendorf Vacfuge plus (Eppendorf, Hauppauge, NY). Extractions were

279 quantified with AccuBlue (Biotium, Inc, Hayward, CA) high sensitivity dsDNA quantification

280 kit and measured on a SpectraMax M2 microplate reader (Molecular Devices, Sunnyvale, CA).

281 All extractions were subsequently stored at $-20^{\circ} \mathrm{C}$ until used for library preparation as outlined

282 below.

283 Size-selected reduced representation genomic libraries were generated following the

284 ezRAD protocol (Toonen et al., 2013; Knapp et al., 2016). In brief, tissue samples were cleaned

285 with Agencourt AMPure XP beads (Beckman Coulter, Indianapolis, IN) following

286 manufacturers' protocols. High molecular weight DNA was digested using the restriction enzyme

287 DpnII to cleave at all GATC cut sites using a final master mix volume of $25 \mu 1(5 \mu 1$ Buffer, 
$28819 \mu 1$ HPLC grade $\mathrm{H}_{2} \mathrm{O}, 1 \mu 1 \mathrm{U}$ DpnII) to $25 \mu 1 \mathrm{dsDNA}(1 \mu \mathrm{g})$. Samples were incubated for 2893 hours at $37^{\circ} \mathrm{C}$ followed by 20 minutes at $65^{\circ} \mathrm{C}$ to denature the enzyme. Following digestion, 290 samples underwent a second bead cleaning with AMPure XP beads. Library preparation for

291 Illumina sequencing was completed with the KAPA HyperPrep kit (Kapa Biosystems,

292 Wilmington, MA) following manufacturers' protocols. All libraries were size selected to retain

293 300-500 base pair (bp) fragments and passed through quality control steps (bioanalyzer and

294 qPCR) prior to high-throughput sequencing. Illumina paired-end fragments were sequenced at

295 the Hawaii Institute of Marine Biology Genetics Core Facility using Illumina v3 2x300 reads on 296 the MiSeq genomic analyzer (Illumina, San Diego, CA).

297

298 Genomic analysis

299 Mitochondrial genome: Raw Illumina reads were paired, trimmed and mapped to the 300 mitochondrial genome of G. robusta (Genbank DQ536424.1) using Geneious v.6.1.8 (Kearse et 301 al., 2012). Five mapping iterations were completed at high sensitivity. For each sample, 302 consensus sequences of all contigs that successfully mapped to the reference genome were 303 extracted, and all consensus sequences were aligned, manually inspected and low coverage 304 regions removed in Geneious.

305

306 Reduced representation nuclear genome: Reads were trimmed, assembled, and genotyped using 307 the dDocent pipeline (Puritz, Hollenbeck \& Gold, 2014). Any loci appearing in less than 85\% of 308 individuals were excluded from these analyses. The paired-end overlapping read algorithm was 309 used for de novo assembly. Clustering similarity of 0.9 and mapping parameters of A (match 310 score $)=2$, B (mismatch score $)=3$, and $\mathrm{O}$ (gap penalty) $=4$ were used. dDocent processing 311 recovered 89,896 loci with an average read depth of 227 in all 19 individuals. Complex variants 312 were decomposed using vcflib (Garrison \& Marth, 2012) to deconstruct haplotypes and 313 insertions and deletions were removed using VCFtools (Danecek et al., 2011). Any contigs that 314 mapped to the mtDNA were removed from the dataset using VCFtools, and the remaining 315 contigs were considered to represent only the nuclear genome. The resulting data were then 316 collapsed into haplotypes with the rad_haplotyper pipeline

317 (https://github.com/chollenbeck/rad_haplotyper; Willis et al., 2017), which uses read alignments 318 to record combinations of SNPs present across paired-end reads. For each individual, 
319 rad_haplotyper removes complex loci, missing data, paralogs, and sequencing errors. Any locus

320 that is not present in at least 14 of 19 individuals with a depth of coverage of at least 20 is not

321 included in the final dataset. The rad_haplotyper method was employed to overcome many of the

322 problems that can arise with SNP data in the absence of a reference genome, such as inflated

323 homozygosity, artifacts, or inflated heterozygosity (Willis et al., 2017). Contigs were then

324 collapsed into genotypes for final analyses. PGDspider v.2.1.1.3 (Lischer \& Excoffier, 2011)

325 was used to convert the dataset to the required file types for further analysis.

326

327 Phylogenetic analysis: The optimal model of sequence evolution was selected using the Akaike

328 Information Criterion (AIC) in JModelTest v.2.1.4 (Posada, 2008). GTR+G was found to be the

329 best-fit substitution model for both the mtDNA and total evidence datasets. The HKY model was

330 found to be the best-fit model for the nuclear dataset. To calculate posterior probabilities of

331 clades, MrBayes v.3.2.6 (Huelsenbeck \& Ronquist, 2001; Ronquist \& Huelsenbec, 2003) was

332 used to run a 1,000,000-generation Markov chain implementing the best-fit model for the

333 dataset. We used flat Dirichlet prior probability densities with an initial burn in of 250,000

334 generations. Trees were saved every 500 generations for a total sample size of 1,500 trees. A

335 majority rule consensus tree calculated from the 2,000 sampled trees was used to determine the

336 posterior probabilities of clades. Under these parameters standard deviations between

337 independent runs stabilized and were all less than 0.01. Maximum likelihood (ML) analyses

338 were conducted using the Randomized Accelerated Maximum Likelihood (RAxML) software

339 v.8 (Stamatakis, 2014). Best-fit models and 30,000 bootstrap replicates were implemented for all

340 datasets. Uncorrected pairwise divergence times for mtDNA were estimated using Mega v.7.0

341 (Kumar, Stecher \& Tamura, 2016). Phylogenetic trees were constructed and visualized using

342 FigTree v.1.4.2 (http://tree.bio.ed.ac.uk/software/figtree/).

343

344 SNAPP Coalescent analysis: Species trees were estimated from the nuclear dataset with the 345 SNAPP package in BEAST v.2.3.2 (Bouckaert et al., 2014). Polymorphic loci were extracted

346 from the rad_haplotyper output and outgroups were removed. BEAUti (Drummond et al., 2012)

347 was executed with the following parameters: all taxa were treated as distinct species/populations,

348 the mutation rates $\mathrm{u}$ and $\mathrm{v}$ were calculated from the data, and default values were used for the

349 exponential priors. The data were then analyzed in BEAST (Bouchaert et al., 2014). The 
350 MCMC chain was run for 10,000,000 generations, sampling every 1,000 generations with

351300,000 preBurnin. The results of this analysis were visualized using Densitree (Bouckaert \&

352 Heled, 2014), and presented as a cloudogram.

353 Molecular clock estimation: To estimate the time of coalescence, a Bayesian MCMC approach

354 was implemented in BEAST on the mtDNA dataset, under a coalescent constant population

355 model with a strict clock of 2\% per million years (Brown, George \& Wilson, 1979; Bowen et al.

356 2011; Reece et al., 2010). Simulations were run with default priors under the GTR + G model of

357 mutation. Simulations were run for 10 million generations, sampling every 1000 generations

358 following a 30,000 preBurnin. Ten independent runs were computed to ensure convergence and

$359 \log$ files were combined using TRACER v.1.7 (Rambaut et al., 2018).

360

361 Tests of Introgression: Tests of introgression were performed on the total dataset using ABBA-

362 BABA statistics implemented in HybridCheck (Ward \& van Oosterhout, 2016) to assess whether

363 introgression with G. cypha could be detected within the G. robusta clades. To ensure that our

364 data met the assumptions of ancestry $((\mathrm{P} 1, \mathrm{P} 2) \mathrm{P} 3)$, required for this test, we only compared in-

365 groups $(\mathrm{P} 1, \mathrm{P} 2)$ separated by the distinct clades of our phylogenetic trees. Standard ABBA-

366 BABA calculations use Patterson's D to infer introgression, but this statistic may not be

367 sufficient to separate introgression from ancestral population structure. Therefore, we also

368 include an alternative statistic $\mathrm{F}_{\mathrm{d}}$ (Martin, Davey \& Jiggins, 2014), which estimates the fraction

369 of the genome shared through complete introgression between P2 and P3, and P1 and P3 and is

370 not subject to the same biases as the D statistic. We also report the statistical significance (p-

371 value) that expressed the deviation from an equal number of ABBA-BABA sites. Significant

372 admixture was determined by $\mathrm{Z}$ scores of 3 or higher.

373

374 Results

375 Taxonomic treatment

376 Gila robusta Baird \& Girard 1853

377 Gila robusta Baird \& Girard 1853. Zuni River, New Mexico. Syntypes: USNM 246 (USNM

$378 \quad 47983 ; 3$, plus 1 pharyngeal arch as \#2798)

379 Gila gracilis Baird \& Girard 1853 (Evermann \& Rutter, 1895; Jordan \& Evermann, 1896;

$380 \quad$ Gilbert \& Scofield, 1898; Gilbert, 1998) 
381

382

383

384

385

386

387

388

389

390

391

392

393

394

395

396

397

398

399

400

401

402

403

404

405

406

407

408

409

410

411

412

413

414

415

416

417

418

419

420

421

422

423

Gila grahamii Baird \& Girard 1853 (Cope, 1871; Evermann \& Rutter, 1895; Jordan \& Evermann, 1896; Fowler, 1924; La Rivers, 1994 [as subspecies: Rinne, 1976; Lee, 1980; Gilbert, 1998])

Gila gibbosa Baird \& Girard 1854 (Jordan \& Gilbert, 1883; Evermann \& Rutter, 1895; Jordan \& Evermann, 1896; Gilbert \& Scofield, 1898; Snyder, 1915; Fowler, 1924; Gilbert, 1998)

Tigoma gibbosa (Baird \& Girard 1854) (Girard, 1856; Jordan \& Gilbert, 1883; Evermann \& Rutter, 1895; Jordan \& Evermann, 1896; Gilbert \& Scofield, 1898; Gilbert \& Scofield, 1898)

Richardsonius gibbosus (Baird \& Girard 1854) (Snyder, 1915)

Tigoma intermedia Girard 1856 (Evermann \& Rutter, 1895; Jordan \& Evermann, 1896; Gilbert \& Scofield, 1898; Fowler, 1924; Snyder, 1915; Gilbert, 1998 [as subspecies: Miller, 1945, 1946; Uyeno \& Miller, 1965; Barber \& Minckley, 1966; La Rivers, 1994] treated as a full species within Gila by Rinne 1969 and most subsequent authors.

Squalius intermedius (Girard 1856) (Jordan \& Gilbert, 1883; Jordan \& Evermann, 1896; Gilbert \& Scofield, 1898)

Leuciscus intermedius (Girard 1856) (Evermann \& Rutter, 1895; Gilbert \& Scofield, 1898; Jordan \& Evermann, 1896; Fowler, 1924)

Ptychocheilus vorax Girard 1856 (Evermann \& Rutter, 1895; Jordan \& Evermann, 1896; La Rivers, 1994)

Gila affinis Abbott 1860 (Jordan \& Evermann, 1896; Fowler, 1924)

Leuciscus zunnensis Günther 1868 (Jordan \& Evermann, 1896; Gilbert \& Scofield, 1898; La Rivers, 1994; Gilbert, 1998)

Leuciscus robustus (Baird \& Girard 1853) (Günther, 1868; Jordan \& Evermann, 1896; La Rivers, 1994)

Leuciscus grahami Günther 1868 (Jordan \& Evermann, 1896)

Gila nacrea Cope 1871 (Evermann \& Rutter, 1895; Jordan \& Evermann, 1896; Gilbert, 1998)

Gila nigra Cope 1875 in Cope \& Yarrow 1875 (Jordan \& Gilbert, 1883; Gilbert \& Scofield, 1898; Snyder, 1915; Fowler, 1924; Gilbert, 1998)

Leuciseus niger (Cope 1875) (Evermann \& Rutter, 1895; Jordan \& Evernmann, 1896; Gilbert \& Scofield, 1898)

Squalius niger (Cope 1875) (Jordan \& Gilbert, 1883; Jordan \& Evermann, 1896)

Squalius nigra (Cope 1875) (Gilbert \& Scofield, 1898, misspelling of S. niger)

Squalius lemmoni Smith 1884 (Jordan \& Evermann, 1896; Gilbert \& Scofield, 1898; Gilbert, 1998)

\section{Morphological analysis}

Type material: Examination of the type series of $G$. robusta $(\mathrm{n}=2)$, G. intermedia $(\mathrm{n}=4)$, G. nigra $(\mathrm{n}=5)$, and G. grahamii $(\mathrm{n}=1)$ reveal differences between the types within this complex.

21 However, similar or greater morphological dissimilarity was observed for the G. grahamii type (now considered a synonym of G. robusta; see above) when compared to each of the other type series (Table 1). Furthermore, these differences apply to only these restricted type series and 
424 differences were not supported when the fresh material was added (see below). Unfortunately, 425 the taxonomic key (Minckley \& Demarias, 2000) used to assign the names G. intermedia and $G$. 426 nigra to the populations that Rinne $(1969 ; 1976)$ and Minckley \& Demarias (2000) recognize as 427 distinct species fails to correctly assign the type material to the correct species.

429 Fresh material: Analysis of fresh material of specimens assigned to the three species reveals 430 extensive overlap in characters, prohibiting any definable difference between groups (Table 2).

431 There is no single diagnostic character that can be used for species identification of fresh 432 material, with considerable overlap among species in every morphological character. Likewise 433 no suite of characters can distinguish the fresh material by species unambiguously.

435 Comparisons of fresh specimens to type material: Morphological comparisons of type material 436 (Table 1) to fresh specimens (Table 2) also failed to resolve the species as currently recognized 437 (Table 3). Type specimens as well as fresh material exhibit as much or more variation within 438 species as between species. As such, it is impossible to assign any of the fresh specimens back to 439 the type material and thus to species, without location information. No character in putative $G$. 440 robusta specimens could be uniformly assigned back to the type of G. robusta but instead each 441 character was assigned to multiple type series. Only $28 \%$ of the time did a morphological 442 character (Table 1,2) align correctly to the types of G. robusta, while $63 \%$ of the time the 443 characters aligned to G. nigra types and $51 \%$ to $G$. intermedia, with many of the characters 444 aligning with multiple type series (Table 3). Similar patterns are observed with both G. nigra and 445 G. intermedia.

446

447 Molecular analysis: Mapping of the mitochondrial genome resulted in recovery of 14,892 base 448 pairs (bp) of the 16,595 bp reference mtDNA genome. Filtering and haplotyping of the nuclear 449 DNA resulted in a final dataset of 1,292 RAD contigs containing 4,821 haplotypes across all 450 individuals, which consisted of 6,658 polymorphisms across 52,483 total bp of nuclear DNA. 451 Analysis of the mitochondrial genome and nuclear datasets revealed high concordance between 452 tree topologies constructed for each of the datasets using both maximum likelihood and bayesian 453 tree building methods. Only a single discrepancy was observed between the nuclear dataset and 454 mtDNA dataset: the O'Donnell Canyon specimen is assigned to clade 2 in the nuclear tree and 
455 clade 4 in the mtDNA tree (Figure 2, 3), which may be the result of accidental mixing of captive

456 stocks. The results of these molecular analysis are consistent with the morphological finding; $G$.

457 intermedia and G. nigra are not distinct evolutionary units and not distinguishable from $G$.

458 robusta. Likewise, the SNAPP coalescent analysis results plotted as a cloudogram reveal high 459 concordance between tree topologies (Figure 4). Similarly, STRUCTURE (Pritchard, Stephens \&

460 Donnelly, 2000) analysis and discriminate analysis of principle components (DAPC; Jombart,

461 2008) fail to discriminate the nominal taxa (Figure S2).

462

463 Morphological analysis of phylogeny: Comparison of morphological characters to the

464 phylogenetic trees revealed nearly $100 \%$ overlap of morphological characters between each

465 clade (i.e. there was no differentiation in any morphological character between phylogenetic

466 clades; Table 4) and no diagnostic morphological character was identified that could align with

467 the phylogenetic lineages resolved in this study.

468

469 Test of introgression: The ABBA-BABA test between the G. robusta complex and G. cypha 470 revealed significant introgression between many of the locations (Table S2) using Patterson's D 471 statistic. However, as expected, the alternative, $F_{d}$ suggests far fewer locations exhibiting 472 significant introgression. There is evidence for introgression in populations from the Verde River 473 (133), Aravaipa Creek (141), Hot Springs Canyon (125), and Spring Creek-Tonto (132) for both $474 \quad \mathrm{D}$ and $\mathrm{F}_{\mathrm{d}}$.

475

476 Discussion

477 Taxonomy and nomenclature

478 G. robusta, G. intermedia, and G. nigra were originally proposed as distinct species

479 based on the differences observed in the type material, during a time when the natural

480 distribution and variation within this group was unknown. Over the years that followed their

481 description, G. intermedia and G. nigra encountered a complicated history of synonymy.

482 However, once the synonymy stabilized, the consensus was to treat G. intermedia and G. nigra 483 within G. robusta (see systematic and taxonomic review). This synonymy was widely accepted 484 until Rinne $(1969 ; 1976)$ removed $G$. intermedia from synonymy and Minckley \& Demarias 485 (2000) subsequently removed G. nigra from synonymy. 
486 We find no evidence, morphological or genetic, to support the current taxonomy. Examination of 487 fresh material revealed that the morphological variability within each of the currently accepted 488 species precluded any distinguishable differences between groups, and individual specimens 489 could not be unambiguously assigned to any type series. The potential characteristic differences 490 observed between each type series, which were originally thought to represent distinct species, 491 reflects the fact that the number of types within a series does not capture the total morphological 492 variation within populations and therefore does not represent what is observed in nature, where 493 no single sample could be unambiguously assigned to a type series. Different morphological 494 characters assign each individual examined to multiple name-bearing types. This finding is 495 concordant with a robust morphological analysis by Moran et al. (2017), which also could not 496 resolve these fish into nominal taxa and found that morphometrics and meristics failed to 497 distinguish the three species. Their principal components analysis using geometric 498 morphometrics also could not separate out the three species. After removing outliers and 499 assigning specimens to a priori groups Moral et al. (2017) were able to resolve most of the 500 specimens into groups using a canonical variate analysis (CVA). However, the CVA resolved 501 two separate groups of G. robusta and appears to be driven by geographic location rather than by 502 evolutionary relationships. The two locations that overlap between Moran et al. (2017) and the 503 data presented here show that the G. robusta from the Verde River fall out in clade 1 and 504 Aravaipa Creek appear in Clade 3 (Figure 2, 3) in our data. We find no evidence to support the validity of Gila robusta, G. intermedia, and G. nigra under any of the more prominent species concepts (i.e. biological species concept, morphological species concept, evolutionary species concept, phenetic species concept, phylogenetic species concept; Mayr, 1942; Simpson, 1961; Cronquist, 1978; Ridley, 1993; De Queiroz, 2007). Instead, our data appear consistent with phenotypic plasticity for G. robusta, and highlight the importance of undertaking a study to test this hypothesis for this species.

511 It might be argued that introgression within the habitats examined in this study is 512 responsible for the observed morphological and molecular results, but in this regard the 513 International Code of Zoological Nomenclature is clear: "The application of each species-group 514 name is determined by reference to the name-bearing type [Arts. 61, 71-75] of the nominal taxon 515 denoted by the combination in which the species-group name was established" (ICZN, 1999, 516 Article 45.3). In this case, the morphology of the name-bearing types do not correspond with the 
517 forms to which the names have been applied in natural populations. Likewise genetic approaches 518 (both STRUCTURE and DAPC) fail to discriminate among the nominal species groups (Figure S2) 519 and these nominal species do not resolve as monophyletic in the phylogenetic analyses (Figures 520 2-4). Because there are no diagnostic morphological or molecular characters that consistently 521 distinguish the populations to which the names have been applied, the species names should not 522 be applied. The data presented here indicate either a single morphologically plastic species, 523 extant populations that consist almost entirely of hybrid individuals of mixed ancestral lineages, 524 or a combination of both. Thus, based on the inability to unambiguously assign individuals to a 525 single taxonomic category, our corresponding conclusion is to synonymize G. nigra and G.

526 intermedia with G. robusta (the name with priority). This conclusion is reinforced by our

527 findings that the taxonomic key and underlying data used to distinguish G. intermedia and $G$.

528 nigra from G. robusta fail to assign even the type specimens unambiguously to a single species.

529 Using mean differences between populations to justify species distinction subsumes the extent of 530 natural variation within conspecific populations, but also, (as is the case here) can lead to 531 polyphyly within nominal species.

532

\section{Patterns and drivers of variation}

$534 \quad$ Gila intermedia and G. nigra were regarded as distinct species based on mean differences 535 between populations inhabiting different streams (Rinne, 1969; Rinne, 1976; Minckley and 536 Demarias, 2000). Some authors suggest that these patterns are based on environmental 537 differences such as water depth and speed (Miller, 1946; but see Rinne, 1976). Plasticity 538 resulting in a gradation of characters by stream size and current is observed in many species of 539 freshwater fishes (Hubbs, 1940). For example, the bluehead sucker, Catostomus discobolus, 540 varies morphologically according to size and flow of the water it inhabits (Sigler \& Sigler, 541 1979). Similarly, the blacktail shiner, Cyprinella venusta, exhibits morphological variation 542 between steams and reservoirs and the magnitude of morphological change is correlated with 543 size of the reservoir (Haas, Blum \& Heins, 2010). The brook charr, Salvelinus fontinalis, exhibits 544 variation in caudal fin size and body shape with water velocity (Imre, McLaughlin \& Noakes, 545 2002). In each of these cases, the population mean differences in morphology are responses to 546 environmental conditions indicating morphological plasticity rather than diagnostic evolutionary 547 traits that could define species. 
The morphological and molecular patterns observed across the geographic range of these

549

550

551

552

553

554

555

556

557

558

559

560

561

562

563

564

565

566

567

568

569

570

571

572

573

574

575

576

577

578

nominal species have prompted a number of hypotheses. First, present-day taxa may be relics

from the last pluvial period when the wetter climate resulted in higher connectivity, with subsequent post-glaciation aridity resulting in local divergence via selection and genetic drift (Williams et al., 1985; Meffe \& Vrijenhoek, 1988). In this case, selection would drive a phenotypic response in current taxa irrespective of evolutionary history, while drift should result in a geographic component to the phylogeny. Alternatively, perhaps current taxa were once isolated and are now hybridizing, yielding the morphological variation observed today (Gerber, Tibbets \& Dowling, 2001; Osborne et al., 2015; DiBattista et al., 2016). Finally, current taxa may be the result of ancient admixture and subsequent isolation resulting in conflicting morphological and molecular signals for distinguishing species. It is difficult to separate these alternate hypotheses (e.g., Eaton \& Ree, 2013; Merrill et al., 2015; Eaton et al., 2015; Martin et al., 2015) but in the case of $G$. robusta it is likely that a combination of these hypotheses is responsible for the observed patterns. Additional research that focuses on testing each of these alternative hypotheses in a robust way would be necessary to fully understand the mechanisms responsible for the morphological variation observed in this species.

\section{Phylogenomics and hybridization}

With the exception of clade 5, no lineage recovered from the phylogenetic analyses (Figure 2) consists of a single species as currently defined. However, the fact that clade 5 consists exclusively of $G$. nigra may be an artifact of the small geographic area and proximity of sampling locations (Figure 1). Individuals identified as G. nigra also occur in clade 3 with $G$. robusta, so while it is possible clade 5 represents a geographically restricted lineage, additional geographical sampling will similarly likely erode the unity of this clade. In any case, whatever the finding with clade 5, our data are consistent with previous studies based on allozyme, mtDNA, and microsatellite markers that likewise failed to find diagnostic characters among these nominal species (DeMarais, 1992; DeMarais et al., 1992; Dowling \& DeMarais, 1993; Dowling et al., 2015, Marsh, Clarkson \& Dowling, 2017).

The average most recent common ancestor of each of the clades resolved in this study is 63kya (51kya to 76 kya 95 HPD interval) with the most recent common ancestor of all populations 119 kya (97 kya to 140 kya 95\% HPD interval). The divergence times of this group 
579 fall well within the last glacial cycle and with such recent divergence of the populations, it seems

580 likely to be linked to post glacial warming and subsequent transitions from the wetter climate of

581 the Last Glacial Maximum to the more arid climate of today (Williams et al., 1985; Meffe \&

582 Vrijenhoek, 1988).

583 Tests of genomic admixture (hybridization) indicate that G. cypha historically interbred

584 with all three nominal species of the G. robusta complex, or interbred with the recent common

585 ancestor of each of these populations. Despite the fact that G. cypha and G. elegans are currently

586 highly endangered, with ranges restricted to the main stem of the Colorado River, evidence

587 suggests that at one time their ranges may have overlapped. The type locality of both G. robusta

588 and G. elegans is the Zuni River, New Mexico, and types were collected on the same expedition

589 at the same locality. Unfortunately, due to the nature of the ABBA BABA test, we were unable

590 to test for significant introgression between G. elegans and G. robusta.

591 It is possible that introgression may have resulted in phenotypic traits passed from $G$.

592 cypha to G. robusta, contributing to the morphological variation observed here. However, no

593 study assessing the heritability of phenotypes between these species has been conducted to test

594 this hypothesis. Similarly, no test of morphological plasticity with regard to stream condition has

595 been conducted. These deficiencies need to be addressed in order to fully understand the patterns 596 observed within natural populations of this species.

597

598 Management implications

599 Our data do not support the current taxonomy of Gila robusta, G. intermedia, and G.

600 nigra. Instead, we find evidence that may correspond to environmental condition and geography

601 more than currently accepted taxonomy and given the propensity of the cyprinids for

602 introgression (Briolay et al., 1998; Rosenfeld \& Wilkinson, 1989; Demarias et al., 1992;

603 Dowling \& Demarias, 1993; Gerber, Tibbets \& Dowling, 2001), speciation within the Lower

604 Colorado River Basin seems unlikely. Hybridization in fishes is a common occurrence

605 (Allendorf \& Leary, 1988). About 30\% of known hybrids in freshwater fish species belong to the

606 Cyprinidae, with ongoing intergeneric hybridization continuing between species that diverged

607 10-15 million years ago (Briolay et al., 1998). The G. robusta species complex is no different;

608 hybridization producing viable offspring is a common occurrence (Gerber, Tibbets \& Dowling,

609 2001; Marsh, Clarkson \& Dowling, 2017). This history, coupled with the cyclical nature of 
610 glacially driven pluvial periods makes it unlikely that evolutionary forces will induce speciation

611 in the absence of permanent barriers to gene flow. Instead, these populations have likely

612 experienced repeated cycles of isolation during dryer periods, followed by connectivity during

613 wetter periods. At each phase, selective forces could favor different phenotypes in different

614 isolated regions, but without reproductive isolation, these lineages could mix during each cycle.

615 These fluctuating selection regimes combined with introgression could result in the complex

616 array of morphological variation observed within this species. In these circumstances,

617 management should focus on maintaining genetic diversity to ensure long-term persistence.

618 Greater genetic diversity is associated with enhanced mean fitness (Quattro \& Vrijenhoek, 1989;

619 Reed \& Frankham, 2003) and decreased extinction risk (Frankham, 2005a; Evans \& Sheldon,

620 2008), so management should focus on preventing the loss of genetic diversity upon which long-

621 term persistence and adaptability depend (Vrijenhoek, Douglas \& Meffe, 1985; Quattro \&

622 Vrijenhoek, 1989; Frankham, 2005b; Hancock et al., 2011).

623 Why have the nominal G. intermedia and G. nigra persisted as taxonomic entities in the

624 face of much evidence to the contrary? In addition to legitimate uncertainties about evolutionary

625 partitions, these may be examples of geopolitical species (sensu Karl \& Bowen, 1999), with

626 species defined by geography, and taxonomic status subsequently maintained to support

627 conservation priorities. There is currently a heated debate in the literature between

628 conservationists and taxonomists regarding the need for fixed taxonomic entities on which to

629 apply conservation priorities versus the dynamic nature of taxonomy that allows for revision of

630 taxonomic hypotheses with new data, methodology, or insights (Garnett \& Christidis, 2017;

631 Thomson et al., 2018). This situation is likely exacerbated by legislation that emphasizes

632 protections of fixed species, such as the Endangered Species Act, but does not allow for

633 taxonomic revision and advancement. For instance, during heated debate over the taxonomy of

634 the endangered green sea turtle (Chelonia mydas), Karl \& Bowen (1999; see also Bowen \& Karl,

635 1999) observed that there are scientifically sound reasons for conservation of isolated

636 populations (which is also true within G. robusta in this case), but nominal taxonomy is not one

637 of them. Conservation priorities may change over time to allow adaptive management, but

638 taxonomy should only be influenced by scientific data as applied through the rules of the ICZN.

639 As with the green sea turtle, the conservation status of these fishes remains a separate issue, but

640 taxonomic assignments that do not meet the standards of the Code should be put aside to allow 
641 researchers to reassess the true relationships within the Gila of the Lower Colorado River Basin.

642 Range-wide genetic surveys should be undertaken to fully identify genetically distinct units, and

643 their geographic extent, in conjunction with thorough morphological analyses to determine

644 species boundaries in this system, which will be facilitated by first purging the incorrectly

645 assigned nomenclature and starting with a clean slate.

646

\section{Conclusions}

648 The results of this study question the validity of the taxonomic names, but do not indicate 649 that protections for this species should cease. Instead our results indicate the need for protection 650 at a population level, to maintain genetic diversity and morphological variation, rather than three 651 nominal species for which no diagnostic morphological or genetic characters exist. The 652 Endangered Species Act defines a species to include "any subspecies of fish or wildlife or plants, 653 and any distinct population segment of any species of vertebrate fish and wildlife which 654 interbreeds when mature" (Section 3(15), ESA 1973, 1978). Neither our data, nor that of 655 previous studies, indicate a single well-mixed population across the Lower Colorado River 656 Basin. In fact, based on previous work, genetic structure may exist among many of the 657 populations analyzed, but this population structure is not aligned with the three currently 658 recognized taxonomic units; the shallow divergences between samples is indicative of population 659 differences, but no species level genetic divergence has been observed. Our study was designed 660 to examine a phylogenetic question and sampling was not sufficient for addressing population 661 level questions. Thus, while these data indicate such population genetic studies are warranted, we 662 caution against inferring population level conclusions until such robust surveys are completed.

663 We recommend that this species be managed as distinct population segments until the additional 664 studies outlined herein are completed.

665

\section{Acknowledgements}

667 We thank Richard Pyle of the Bishop Museum for assistance with taxonomy and nomenclature 668 as well as his knowledge of the ICZN Code. We also thank Matthew O'Neill, Clay Crowder, and 669 Julie Carter of the Arizona Game and Fish Department; Cassie Ka'apu-Lyons, Emily Conklin, 670 Mykle Hoban, Ingrid Knapp, Mahdi Belcaid, Anne Lee and the ToBo Lab members at the 671 Hawaii Institute of Marine Biology; Jon Puritz at University of Rhode Island for his help with 
672 dDocent; Anthony Montgomery at the USFW; and Sandra Raredon and Jeff Williams of the

673 National Museum for their assistance with the type material. Thanks to editors James Reimer and

674 two anonymous reviewers for comments and suggestions that greatly improved the manuscript.

675 This is University of Hawaii School of Ocean and Earth Science and Technology contribution

$676 \mathrm{XXXX}$ and Hawaii Institute of Marine Biology contribution xxxx.

677

678 Reference

679 Abbott CC. 1860. Description of four new species of North American Cyprinidae. Proceedings

680 of the Academy of Natural Sciences of Philadelphia 12:473-474.

681 Allendorf FW, Leary RF. 1988. Conservation and distribution of genetic variation in a polytypic

682

683

684

685

686

687

688

689

690

691

692

693

694

695

696

697

698

699

700

701

702

703

704

705

706

707

708

709

710

711

712

713 species, the cutthroat trout. Conservation Biology 2:170-184.

Ayres WO. 1854. Description of new fishes from California. The Pacific [newspaper] v.3 and 4 (thru no. 6).

Baird SF, Girard CF. 1853a. Descriptions of some new fishes from the River Zuni. Proceedings of the Academy of Natural Sciences, Philadelphia 6:368-369.

Baird SF, Girard CH. 1853b. Descriptions of new species of fishes collected by Mr. John H. Clark, on the US and Mexican boundary Survey, under Lt. Col. Jas. D. Graham. Proceedings of the Academy of Natural Sciences, Philadelphia 6:387-390.

Baird SF, Girard CF. 1854. Descriptions of new species of fishes collected in Texas, New Mexico and Sonora, by Mr. John H. Clark, on the US and Mexican boundry survy and in Texas by Capt. Stewart Van Vliet, USA. Proceedings of the Academy of Natural Sciences, Philadelphia 7:24-29.

Barber WE, Minckley WL. 1966. Fishes of Aravaipa Creek, Graham and Pinal Counties, Arizona. The Southwestern Naturalist 11:313-324.

Baxter GT, Stone MD. 1995. Fishes of Wyoming. Cheyenne: Wyoming Game and Fish Department.

Bonaparte CL. 1837. Iconographia della fauna Italica per le quatro classi degli animali vertebrati. (Vol.3) Salviucci.

Bouckaert R, Heled J. 2014. DensiTree 2: Seeing trees through the forest. bioRxiv. http://dx.ddoi.org/10.11.01/012401

Bouckaert R, Heled J, Kühnert D, Vaughan T, Wu C, Xie D, Suchard MA, Rambaut A, Drummond AJ. 2014. BEAST 2: a software platform for Bayesian evolutionary analysis. PLoS computational biology 10:e1003537.

Bowen BW. 2016. The three domains of conservation genetics: Case histories from Hawaiian waters. Journal of Heredity 107:309-317.

Bowen BW, Karl SA. 1999. In war, truth is the first casualty. Conservation Biology 13:10131016.

Bowen BW, Bass A, Rocha L, Grant W, Robertson DR. 2001. Phylogeography of the trumpetfishes (Aulostomus): ring species complex on a global scale. Evolution 55:10291039.

Briolay J, Galtier N, Brito RM, Bouvet Y. 1998. Molecular phylogeny of cyprinidae inferred fromcytochrome bDNA Sequences. Molecular phylogenetics and evolution 9:100-108. 
714 Brown WM, George M, Wilson AC. 1979. Rapid evolution of animal mitochondrial DNA.

715

716

717

718

719

720

721

722

723

724

725

726

727

728

729

730

731

732

733

734

735

736

737

738

739

740

741

742

743

744

745

746

747

748

749

750

751

752

753

754

755

756

757

758
Proceedings of the National Academy of Sciences 76:1967-1971.

Carter JM, Clement MJ, Makinster AS, Crowder CD, Hickerson BT. 2018. Classification Success of Species within the Gila robusta Complex Using Morphometric and Meristic Characters-A Reexamination. Copeia 106:279-291.

Cole GA. 1968. Desert limnology. In: Brown GW, ed. Desert biology: Elsevier.

Cope ED. 1871. Recent reptiles and fishes. Report on the reptiles and fishes obtained by the naturalists of the expedition. U.S. Geological Survey of Wyoming \& Contiguous Territories. 4: 432-442.

Cope ED. 1872. Report on the recent reptiles and fishes of the survey collected by Campbell, Carrington, and CB Dawes. Preliminary report of the US Geological Survey of Territories, 1872. US Geological Survey, Washington, DC 5: 467-476.

Cope ED, Yarrow HC. 1875. Report upon the collections of fishes made in portions of Nevada, Utah, California, Colorado, New Mexico, and Arizona, during the years 1871, 1872, 1873, and 1874. Engineer Department, United States Army. Report upon the Geographical and Geological Explorations and Surveys west of the one hundredth Meridian v. 5 (Zoology) Chapter 6: 635-703

Cronquist A. 1978. Once again, what is a species? Biosystematics in agriculture. Beltsville Symposia in Agr Res. p 3-20.

Cuvier G. 1816. Le règne animal distribué d'après son organisation, pour servir de base à l'histoire naturelle des animaux et d'introduction a [sic] l'anatomie comparée. Tome II Les reptiles, les poissons, les mollusques et les annelids 18:1-532.

Danecek P, Auton A, Abecasis G, Albers CA, Banks E, DePristo MA, Handsaker RE, Lunter G, Marth GT, Sherry ST. 2011. The variant call format and VCFtools. Bioinformatics 27:2156-2158.

De Queiroz K. 2007. Species concepts and species delimitation. Systematic biology 56:879-886.

DeMarais BD. 1992. Genetic relationships among fishes allied to the genus Gila (Teleostei: Cyprinidae) from the American Southwest. PhD dissertation, Arizona State University.

DeMarais, BD, Dowling TE, Douglas ME, Minckley WL, Marsh PC. 1992. Origin of Gila seminuda (Teleostei: Cyprinidae) through introgressive hybridization: implications for evolution and conservation. Proceedings of the National Academy of Sciences, 89: 27472751.

DiBattista JD, Gaither MR, Hobbs JA, Rocha LA, Bowen BW. 2016. Angelfishes, Paper Tigers, and the Devilish Taxonomy of the Centropyge flavissima complex. Journal of Heredity 107:647-653.

Dowling TE, DeMarais BD. 1993. Evolutionary significance of introgressive hybridization in cyprinid fishes. Nature 362:444.

Dowling TE, Anderson CD, Marsh PC, Rosenberg MS. 2015. Population structure in the Roundtail Chub (Gila robusta complex) of the Gila River basin as determined by microsatellites: evolutionary and conservation implications. PloS one 10:e0139832.

Drummond AJ, Suchard MA, Xie D, Rambaut A. 2012. Bayesian phylogenetics with BEAUti and the BEAST 1.7. Molecular biology and evolution 29:1969-1973.

Eaton DA, Ree RH. 2013. Inferring phylogeny and introgression using RADseq data: an example from flowering plants (Pedicularis: Orobanchaceae). Systematic biology 62:689706. 
759

760

761

762

763

764

765

766

767

768

769

770

771

772

773

774

775

776

777

778

779

780

781

782

783

784

785

786

787

788

789

790

791

792

793

794

795

796

797

798

799

800

801

802

803

804

Eaton, DA, Hipp A, Gonzalez-Rodriguez A, Cavender-Bares J. 2015. Historical introgression among the American live oaks and the comparative nature of tests for introgression. Evolution, 69:2587-2601

Ellis MM. 1914. Fishes of Colorado: University of Colorado studies 11:1-135.

Espinosa-Pérez H, Gaspar-Dillanes M, Fuentes-Mata P. 1993. Listados Faunısticos de Mexico III Los peces dulceacuicolas mexicanos. Instituto de Biologia Univ Nac Auton Mex, Mexico:62.

Evans SR, Sheldon BC. 2008. Interspecific patterns of genetic diversity in birds: correlations with extinction risk. Conservation Biology 22:1016-1025.

Evermann BW, Rutter C. 1895. The fishes of the Colorado Basin. US Fish Commission Bulletin 14:473-486.

Fowler HW. 1924. Notes on North American cyprinoid fishes. Proceedings of the Academy of Natural Sciences of Philadelphia 76:389-416.

Frankham R. 2005a. Genetics and extinction. Biological conservation 126:131-140.

Frankham R. 2005b. Stress and adaptation in conservation genetics. Journal of evolutionary biology 18:750-755.

Gaither MR, Szabó Z, Crepeau MW, Bird CE, Toonen RJ. 2011. Preservation of corals in saltsaturated DMSO buffer is superior to ethanol for PCR experiments. Coral Reefs 30:329333.

Garnett ST, Christidis L. 2017. Taxonomy anarchy hampers conservation. Nature News 546:25. https://doi.org/10.1038/546025a PMID: 28569833

Garrison E, Marth G. 2012. Haplotype-based variant detection from short-read sequencing. arXiv preprint arXiv: 12073907.

Gerber AS, Tibbets CA, Dowling TE. 2001. The role of introgressive hybridization in the evolution of the Gila robusta complex (Teleostei: Cyprinidae). Evolution 55:2028-2039.

Gilbert CH, Scofield NB. 1898. Notes on a collection of fishes from the Colorado Basin in Arizona. Proceedings of the United States National Museum 20:487-499.

Gilbert CR. 1998. Type catalogue of recent and fossil North American freshwater fishes: families Cyprinidae, Catostomidae, Ictaluridae, Centrarchidae and Elassomatidae: Florida Museum of Natural History, University of Florida.

Girard C. 1856. Researches upon the cyprinoid fishes inhabiting the fresh waters of the United States, west of the Mississippi Valley, from specimens in the museum of the Smithsonian Institution. Proceedings of the Academy of Natural Sciences of Philadelphia 8:165-213.

Girard C. 1858. Fishes. General report upon zoology of the several Pacific railroad routes, 1857. In: Reports of explorations and surveys, to ascertain the most practicable and economical route for a railroad from the Mississippi River to the Pacific Ocean, v. 10. Beverley Tucker, Washington, D.C. [Part of Senate Ex. Doc. No. 78 (33rd Congress, 2nd Sess.).

Günther A. 1868. Catalogue of the Physostomi, Containing the Families Heteropygii, Cyprinidae, Gonorhynchidae, Hyodontidae, Osteoglossidae, Clupeidae, Chirocentridae, Alepocephalidae, Notopteridae, Halosauridae, in the Collection of the British Museum. Catalog of fishes 7:1-512

Haas TC, Blum MJ, Heins DC. 2010. Morphological responses of a stream fish to water impoundment. Biology letters 6:803-806.

Hancock AM, Brachi B, Faure N, Horton MW, Jarymowycz LB, Sperone FG, Toomajian C, Roux F, Bergelson J. 2011. Adaptation to climate across the Arabidopsis thaliana genome. Science 334:83-86. 
805

806

807

808

809

810

811

812

813

814

815

816

817

818

819

820

821

822

823

824

825

826

827

828

829

830

831

832

833

834

835

836

837

838

839

840

841

842

843

844

845

846

847

848

849

850

Hocutt CH, Wiley EO. 1986. The zoogeography of North American freshwater fishes: WileyInterscience, New York.

Holden P, Minckley W. 1980. Gila cypha Miller, humpback chub. Atlas of North American freshwater fishes North Carolina Museum of Natural History, Raleigh:165.

Hubbs CL. 1940. Speciation of fishes. The American Naturalist 74:198-211.

Hubbs CL, Lagler KF. 1958. Fishes of the Great Lakes region (revised). Cranbrook Inst Sci Bull 26:1-213.

Hulsenbeck JP, Ronquist F. 2001. MrBayes: Bayesian inference of phylogeny. Bioinformatics 17:754-755.

Imre I, McLaughlin RL, Noakes DL. 2002. Phenotypic plasticity in brook charr: changes in caudal fin induced by water flow. Journal of Fish Biology 61:1171-1181.

International Commission of Zoological Nomenclature 1999 International code of zoological nomenclature. Fourth edition. The International Trust for Zoological Nomenclature, c/o Natural History Museum, London. i-xxix, +306 pp.

Jombart T. 2008. adegenet: a R package for the multivariate analysis of genetic markers Bioinformatics 24:1403-1405. doi: 10.1093/bioinformatics/btn129

Jordan DS, Gilbert CH. 1883. Synopsis of the fishes of North America: US Government Printing Office 16.

Jordan DS, Evermann BW. 1896. The fishes of North and Middle America: a descriptive catalogue of the species of fish-like vertebrates found in the waters of North America, north of the Isthmus of Panama: US Government Printing Office.

Karl SA, Bowen BW. 1999. Evolutionary significant units versus geopolitical taxonomy: molecular systematics of an endangered sea turtle (genus Chelonia). Conservation Biology 13:990-999.

Kearse M, Moir R, Wilson A, Stones-Havas S, Cheung M, Sturrock S, Buxton S, Cooper A, Markowitz S, Duran C. 2012. Geneious Basic: an integrated and extendable desktop software platform for the organization and analysis of sequence data. Bioinformatics 28:1647-1649.

Knapp I, Puritz J, Bird C, Whitney J, Sudek M, Forsman Z, Toonen R. 2016. ezRAD- an easy next-gen RAD sequencing protocol_v3.1. DOI: 10.17504/protocols.io.e9pbh5n

Kumar S, Stecher G, Tamura K. 2016. MEGA7: molecular evolutionary genetics analysis version 7.0 for bigger datasets. Molecular biology and evolution 33:1870-1874.

LaRivers I. 1962. Fish and fisheries of Nevada. Nevada State Fish and Game Commission, Carson City. Republished 1994. University of Nevada Press, Reno.

La Rivers I. 1994. Fishes and fisheries of Nevada: University of Nevada Press.

Lee DS, Gilbert CR, Hocutt CH, Jenkins RE, McAllister DE, Stauffer Jr JR. 1980. Atlas of North American freshwater fishes. Publication of the North Carolina biological survey 12:1867.

Lischer HE, Excoffier L. 2011. PGDSpider: an automated data conversion tool for connecting population genetics and genomics programs. Bioinformatics 28:298-299.

Marsh PC, Clarkson RW, Dowling TE. 2017. Molecular genetics informs spatial segregation of two desert stream Gila species. Transactions of the American Fisheries Society 146:4759.

Martin CH, Cutler JS, Friel JP, Dening Touokong C, Coop G, Wainwright PC. 2015. Complex histories of repeated gene flow in Cameroon crater lake cichlids cast doubt on one of the clearest examples of sympatric speciation. Evolution 69:1406-1422. 
851

852

853

854

855

856

857

858

859

860

861

862

863

864

865

866

867

868

869

870

871

872

873

874

875

876

877

878

879

880

881

882

883

884

885

886

887

888

889

890

891

892

893

894

895

Martin SH, Davey JW, Jiggins CD. 2014. Evaluating the use of ABBA-BABA statistics to locate introgressed loci. Molecular biology and evolution 32:244-257.

Mayden RL. 1992. Systematics, historical ecology, and North American freshwater fishes. Stanford: Stanford University Press.

Mayr E. 1942. Systematics and the origin of species. Columbia University. Press.

Meffe GK, Vrijenhoek RC. 1988. Conservation genetics in the management of desert fishes. Conservation Biology 2:157-169.

Merrill RM, Dasmahapatra KK, Davey JW, Dell'Aglio D, Hanly J, Huber B, Jiggins CD, Joron M, Kozak K, Llaurens V. 2015. The diversification of Heliconius butterflies: what have we learned in 150 years? Journal of evolutionary biology 28:1417-1438.

Miller RR. 1945. A new cyprinid fish from southern Arizona, and Sonora, Mexico, with the description of a new subgenus of Gila and a review of related species. Copeia 1945:104110.

Miller RR. 1946. Gila cypha, a remarkable new species of cyprinid fish from the lower Colorado River basin, Arizona. Journal Washington Academy Science 36:206-212.

Miller RR. 1961. Man and the changing fish fauna of the American Southwest. Michigan Academy of Science, Arts, and Letters 46:365-404.

Miller RR. 2005. Freshwater fishes of México. Chicago: University of Chicago Press.

Miller RR, Lowe CH. 1964. Annotated checklist of the fises of Arizona. In: The vertebrates of Arizona. Tucson: University of Arizona Press.

Miller RR, Lowe CH. 1967. Fishes of Arizona. In: The Vertebrates of Arizona Tuscon: University of Arizona Press, 133-151.

Minckley WL. 1969. Aquatic biota of the Sonoita Creek basin, Santa Cruz County, Arizona. Nature Conservancy, Ecological Studies Leaflet 15:1-8.

Minckley W. 1971. Keys to native and introduced fishes of Arizona. Journal of the Arizona Academy of Science 6:183-188.

Minckley WL. 1973. Fishes of Arizona. Publication of the Arizona Game and Fish Department. Minckley WL, Alger NT. 1968. Fish remains from an archaeological site along the Verde River, Yavapai County, Arizona. Plateau 40:91-97.

Minckley WH, Hendrickson DA; Bond CE. 1986. Geography of western North American freshwater fishes: description and relationships to intracontinental tectonism. The zoogeography of North American freshwater fishes:519-613.

Minckley WL, DeMarais BD. 2000. Taxonomy of chubs (Teleostei, Cyprinidae, Genus Gila) in the American southwest with comments on conservation. Copeia 2000:251-256.

Minckley W, Marsh PC. 2009. Inland fishes of the greater Southwest: chronicle of a vanishing biota: University of Arizona Press.

Moran C, O'Neill M, Armbruster J, Gibb A. 2017. Can members of the southwestern Gila robusta species complex be distinguished by morphological features? Journal of Fish Biology 91:302-316.

Nelson JS, Crossman EJ, Espinosa-Pérez H, Findley LT, Gilbert CR, Lea RN, Williams JD. 2004. Common and scientific names of fishes from the United States, Canada and Mexico: American Fisheries Society.

Norris S, Fischer J, Minckley W. 2003. Gila brevicauda (Teleostei: Cyprinidae), a new species of fish from the Sierra Madre Occidental of Mexico. Ichthyological Exploration of Freshwaters 14:19-30. 
896 Osborne MJ, Diver TA, Hoagstrom CW, Turner TF. 2016. Biogeography of Cyprinella lutrensis:

897

898

899

900

901

902

903

904

905

906

907

908

909

910

911

912

913

914

915

916

917

918

919

920

921

922

923

924

925

926

927

928

929

930

931

932

933

934

935

936

937

938

939

940

941 intensive genetic sampling from the Pecos River 'melting pot'reveals a dynamic history and phylogenetic complexity. Biological journal of the Linnean Society 117:264-284.

Page LM, Burr BM. 2011. Peterson field guide to freshwater fishes of North America north of Mexico: Second Edition. San Diego:Houghton Mifflin Harcourt.

Page LM, Espinosa-Pérez H, Findley LD, Gilbert CR, Lea RN, Mandrak NE, Mayden RL, Nelson JS. 2013. Common and scientific names of fishes from the United States. Canada, and Mexico, Bethesda, Maryland: American Fisheries Society 7th edition, Special Publication 34.

Page LM, Baldwin CC, Espinosa-Pérez H, Findley LT, Gilbert CR, Hartel KE, Lea RN, Mandrak NE, Schmitter-Soto JJ, Walker Jr H. 2017. Taxonomy of Gila in the Lower Colorado River Basin of Arizona and New Mexico: Committee on Names of Fishes, a joint committee of the American Fisheries Society and the American Society of Ichthyologists and Herpetologists. Fisheries 42:456-460.

Posada D. 2008. jModelTest: phylogenetic model averaging. Molecular biology and evolution 25:1253-1256.

Pritchard JK, Stephens M, Donnelly, P. 2000. Inference of population structure using multilocus genotype data. Genetics 155:945-959.

Puritz JB, Hollenbeck CM, Gold JR. 2014. dDocent: a RADseq, variant-calling pipeline designed for population genomics of non-model organisms. PeerJ 2:e431.

Quattro JM, Vrijenhoek RC. 1989. Fitness differences among remnant populations of the endangered Sonoran topminnow. Science 245:976-978.

R Core Team 2016. R: A language and environment for statistical computing. R Foundation for Statistical Computing, Vienna, Austria. URL http://www.R-project.org/.

Rambaut A. 2014. TreeAnnotator v. 2.3. 0. Part of the BEAST package.

Rambaut A, Drummond AJ, Xie D, Baele G, Suchard MA. 2018. Tracer v.1.7, Available from http://beast.community/tracer.

Reece JS, Bowen BW, Smith DG, Larson A. 2010. Molecular phylogenetics of moray eels (Muraenidae) demonstrates multiple origins of a shell-crushing jaw (Gymnomuraena, Echidna) and multiple colonizations of the Atlantic Ocean. Molecular phylogenetics and evolution 57:829-835.

Reed DH, Frankham R. 2003. Correlation between fitness and genetic diversity. Conservation Biology 17:230-237.

Ridley M. 1993. Evolution: Boston, Blackwell Scientific Publications.

Rinne JN. 1969. Cyprinid fishes of the genus Gila from the lower Colorado River basin. Arizona State University.

Rinne JN. 1976. Cyprinid fishes of the Gila from the lower Colorado River. Wassman Journal of Biology 34:65-107.

Robins CR. 1991. Common and scientific names of fishes from the United States and Canada. Special publication/American Fisheries Society (USA).

Robins CR, Bailey RM, Bond CE. 1980. A list of common and scientific names of fishes from the United States and Canada: American Fisheries Society.

Ronquist F, Huelsenbeck JP. 2003. MrBayes 3: Bayesian phylogenetic inference under mixed models. Bioinformatics 19:1572-1574.

Rosenfeld MJ, Wilkinson JA. 1989. Biochemical genetics of the Colorado River Gila complex (Pisces: Cyprinidae). The Southwestern Naturalist:232-244. 
942 Scharpf C. 2005. Annotated checklist of North American freshwater fishes, including subspecies 943 and undescribed forms. Part I: Petromyzontidae through Cyprinidae Am Curr 31:1-44.

944 Schönhuth S, Shiozawa DK, Dowling TE, Mayden RL. 2012. Molecular systematics of western

945

946

947

948

949

950

951

952

953

954

955

956

957

958

959

960

961

962

963

964

965

966

967

968

969

970

971

972

973

974

975

976

977

978

979

980

981

982

983

984

985

986

987 North American cyprinids (Cypriniformes: Cyprinidae). Zootaxa 3586:281-303.

Schönhuth S, Perdices A, Lozano-Vilano L, García-de-León FJ, Espinosa-Pérez H, Mayden RL. 2014. Phylogenetic relationships of North American western chubs of the genus Gila (Cyprinidae, Teleostei), with emphasis on southern species. Molecular phylogenetics and evolution 70:210-230.

Seutin G, White BN, Boag PT. 1991. Preservation of avian blood and tissue samples for DNA analyses. Canadian Journal of Zoology 69:82-90.

Sigler W, Miller R. 1963. Fishes of Utah: Salt Lake City, Utah Dept Fish and Game.

Sigler WF, Sigler JW. 1996. Fishes of Utah: a natural history: Salt Lake City, University of Utah Press.

Simpson GG. 1961. Principles of animal taxonomy.

Smith GR, Miller RR, Sable W. 1979. Species relationships among fishes of the genus Gila in the upper Colorado River drainage. Ann Arbor 1001:48109.

Smith R. 1884. Description of a new species of Squalius Bonaparte 1837. Bulletin of the California Academy of Sciences 1:3-4.

Snyder JO. 1915. Notes on a collection of fishes made by Dr. Edgar A. Mearns from rivers tributary to the Gulf of California. Proceedings of the United States National Museum 49:573-586.

Stamatakis A. 2014. RAxML version 8: a tool for phylogenetic analysis and post-analysis of large phylogenies. Bioinformatics 30:1312-1313.

Storer D. 1845. Descriptions of species of fishes. Boston Journal of Natural History 2:48-49.

Stout GG, Bloom EC, Glass JK. 1970. The fishes of Cave Creek, Maricopa County, Arizona. Journal of the Arizona Academy of Science 6:109-113.

Sublette E, Hatch D, Sublette M. 1990. The fishes of New Mexico: University of New Mexico Press.

Tanner VM. 1950. A new species of Gila from Nevada (Cyprinidae). The Great Basin Naturalist 10:31-36.

Thomson SA, Pyle RL, Ahyong ST, Alonso-Zarazaga M, ..., Copus JM, ... 2018. Taxonomy based on science is necessary for global conservation. PLoS biology 16:e2005075.

Toonen RJ, Puritz JB, Forsman ZH, Whitney JL, Fernandez-Silva I, Andrews KR, Bird CE. 2013. ezRAD: a simplified method for genomic genotyping in non-model organisms. PeerJ 1:e203.

USFWS. 2005. Endangered and threatened wildlife and plants; Listing Gila Chub as endangered with critical habitat; Final rule. Federal Register 70:66664-66721.

USFWS. 2015. Endangered and threatened wildlife and plants: threatened species status for the Headwater Chub and a distinct population segment of the Roundtail Chub. Federal Register 80:60754-60783.

Uyeno T. 1961. Osteology and phylogeny of the American cyprinid fishes allied to the genus Gila. University of Michigan.

Uyeno T, Miller RR. 1965. Middle Pliocene cyprinid fishes from the Bidahochi formation, Arizona. Copeia:28-41.

Vanicek CD. 1967. Ecological Studies of Native Greenriver Fishes Below Flaming Gorge Dam, 1964-1966. Unpulb. Ph.D. diss. 
988 Vrijenhoek RC, Douglas ME, Meffe GK. 1985. Conservation genetics of endangered fish

989

990

991

992

993

994

995

996

997

998

999

1000

1001

1002

1003

1004

1005

1006

1007

1008

1009

1010

1011

1012

1013

1014

1015

1016

1017

1018

1019

1020

1021

1022

1023

1024

1025

1026

1027

1028

1029

1030

1031 populations in Arizona. Science 229:400-402.

Ward BJ, Oosterhout C. 2016. HYBRIDCHECK: software for the rapid detection, visualization and dating of recombinant regions in genome sequence data. Molecular ecology resources 16:534-539.

Williams JE, Bowman DB, Brooks JE, Echelle AA, Edwards RJ, Hendrickson DA, Landye JJ. 1985. Endangered aquatic ecosystems in North American deserts with a list of vanishing fishes of the region. Journal of the Arizona-Nevada Academy of Science:1-61.

Willis SC, Hollenbeck CM, Puritz JB, Gold JR, Portnoy DS. 2017. Haplotyping RAD loci: an efficient method to filter paralogs and account for physical linkage. Molecular ecology resources 17:955-965.

Winfield I, Nelson JS. 1991. Cyprinid fishes: systematics, biology and exploitation. Vol. 3. Springer Science \& Buisness Media.

\section{Tables and Figures}

Table 1: Morphometric and meristic analysis of the type series of G. robusta, G. nigra, G. intermedia, and G. grahamii for 32 morphological variables presented as a proportion of standard length $^{1}$, head length ${ }^{2}$, or body depth ${ }^{3}$.

Table 2: Morphometric and meristic analysis of the fresh samples of G. robusta, G. nigra, G. intermedia, and G. grahamii for 36 morphological variables presented as a proportion of standard length $^{1}$, head length ${ }^{2}$, or body depth ${ }^{3}$.

Table 3: Proportion of 22 variables that were assigned to each of the type series for each of the fresh specimens examined with proportion that were unable to assign being labeled as unclassified. Due to overlap in morphometrics, proportions can add up to greater than 1 .

Table 4: Range of morphometrics and meristics by phylogenetic clade for 31 variables. Morphometrics presented as a proportion of standard length ${ }^{1}$, head length ${ }^{2}$, or body depth ${ }^{3}$.

Figure 1: Map of collecting locations. Circles indicate collecting location of fresh material; squares represent locality of type series for G. robusta (red) G. intermedia (black) and G. nigra (blue) and G. grahamii (green). Collecting locations of type material are approximations based on original reports. Grey shaded areas with black outline indicate the upper Colorado River basin (dark grey) and lower Colorado River Basin (light grey) and currently recognized ranges based on IUCN Red List maps are for G. robusta (red) G. nigra (blue) and G. intermedia (black diagonal stripes) are also printed.

Figure 2: Phylogenetic tree of mtDNA genome resulting from Bayesian Inference for each specimen. Color indicates taxonomic assignment of each sample for G. robusta (red) $G$. intermedia (black) and G. nigra (blue). Tree rooted with G. cypha and G. elegans. Node labels are Bayesian probabilities and Maximum likelihood bootstraps. 
1032 Figure 3: Phylogenetic tree of nuclear DNA dataset resulting from Bayesian Inference for each 1033 specimen. Color indicates taxonomic assignment of each sample for G. robusta (red) $G$.

1034 intermedia (black) and G. nigra (blue). Tree rooted with G. cypha and G. elegans. Node labels 1035 are Bayesian probabilities and Maximum likelihood bootstraps.

1036

1037

1038

1039

1040

1041

\section{Supplementary Material}

1043 Supplementary Figure S1: Photo of note written by R.R. Miller in 1945 explaining error in 1044 catalog numbers of G. robusta reported by Jordan and Evermann 1896:227. This note is included with the type specimens of this species.

Figure 4: This cloudogram represents the posterior distribution of lineage trees from the Bayesian phylogenetic analysis program SNAPP. Higher density areas indicate greater agreement in tree topologies. Color labels indicate taxonomic assignment of each sample for $G$. robusta (red) G. intermedia (black) and G. nigra (blue).

Supplementary Figure S2: Results of the STRUCTURE analysis and discriminate analysis of principle components of the genetic data for this study. File includes figures and methods for each analysis.

Supplementary Table S1: Results of linear regression test of allometric growth in type material and fresh material examined in this study. Results indicate that variables exhibit isometric scaling, so specimens of different sizes can be compared. F-tests indicate whether each variable has an equal or unequal variance between type material and fresh material. T-test type was selected based on this result. T-tests results were to verify that shrinkage due to preservation was not significant for comparisons of type material and fresh material. No significant difference was observed. phylogenetic clades in this study. Where the p-value represents a significant deviation of ABBA and $\mathrm{BABA}$ negative value of $\mathrm{D}$ means $\mathrm{H} 1$ is closer to $\mathrm{H} 3$ than $\mathrm{H} 2$ a positive means that $\mathrm{H} 2$ is closer to $\mathrm{H} 3$ than $\mathrm{H} 1$, and the $\mathrm{Z}$ scores for $\mathrm{D}$ and the alternate measure of introgression $\mathrm{F}_{\mathrm{d}}$. indicate significant deviations from the mean. We use a $Z$ value of 3 to indicate significant introgression. 
Figure 1 (on next page)

Map of collecting locations

Circles indicate collecting location of fresh material; squares represent locality of type series for G. robusta (red) G. intermedia (black) and G. nigra (blue) and G. grahamii (green). Collecting locations of type material are approximations based on original reports. Grey shaded areas with black outline indicate the upper Colorado River basin (dark grey) and lower Colorado River Basin (light grey) and currently recognized ranges based on IUCN Red List maps are for G. robusta (red) G. nigra (blue) and G. intermedia (black diagonal stripes) are also printed. 


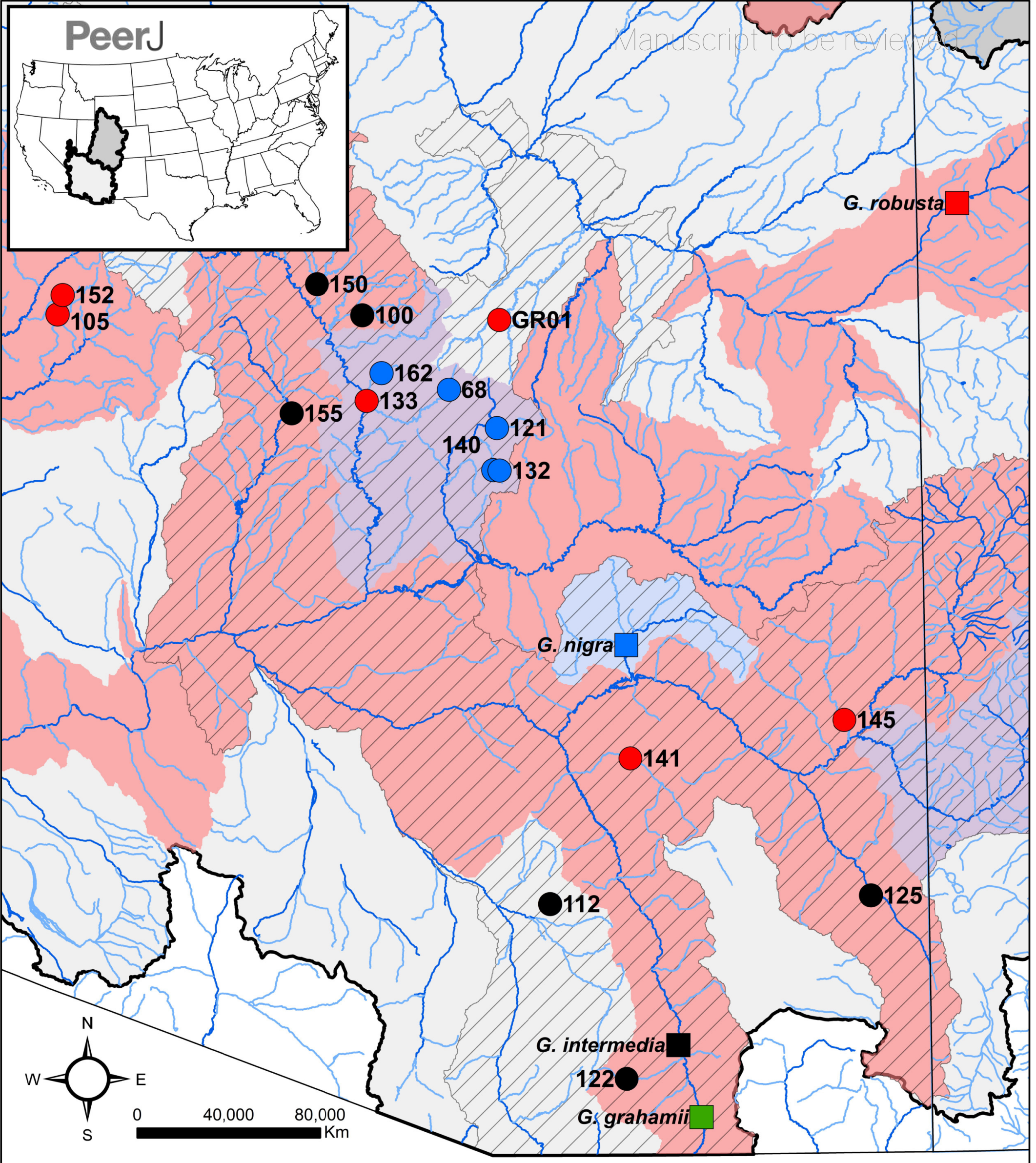

Collection Locations Type Locations

Range Map

\section{Colorado River Basin}

G. intermedia

G. intermedia

G. intermedia

Upper Colorado

G. nigra

G. nigra

G. nigra

Lower Colorado

G. robusta

G. robusta

G. robusta 


\section{Figure 2 (on next page)}

\section{mtDNA phylogenetic reconstruction}

Phylogenetic tree of mtDNA genome resulting from Bayesian Inference for each specimen. Color indicates taxonomic assignment of each sample for $G$. robusta (red) G. intermedia (black) and G. nigra (blue). Tree rooted with G. cypha and G. elegans. Node labels are Bayesian probabilities and Maximum likelihood bootstraps. 
Figure 3 (on next page)

Nuclear phylogenetic reconstruction

Phylogenetic tree of nuclear DNA dataset resulting from Bayesian Inference for each specimen. Color indicates taxonomic assignment of each sample for $G$. robusta (red) $G$. intermedia (black) and G. nigra (blue). Tree rooted with G. cypha and G. elegans. Node labels are Bayesian probabilities and Maximum likelihood bootstraps. 


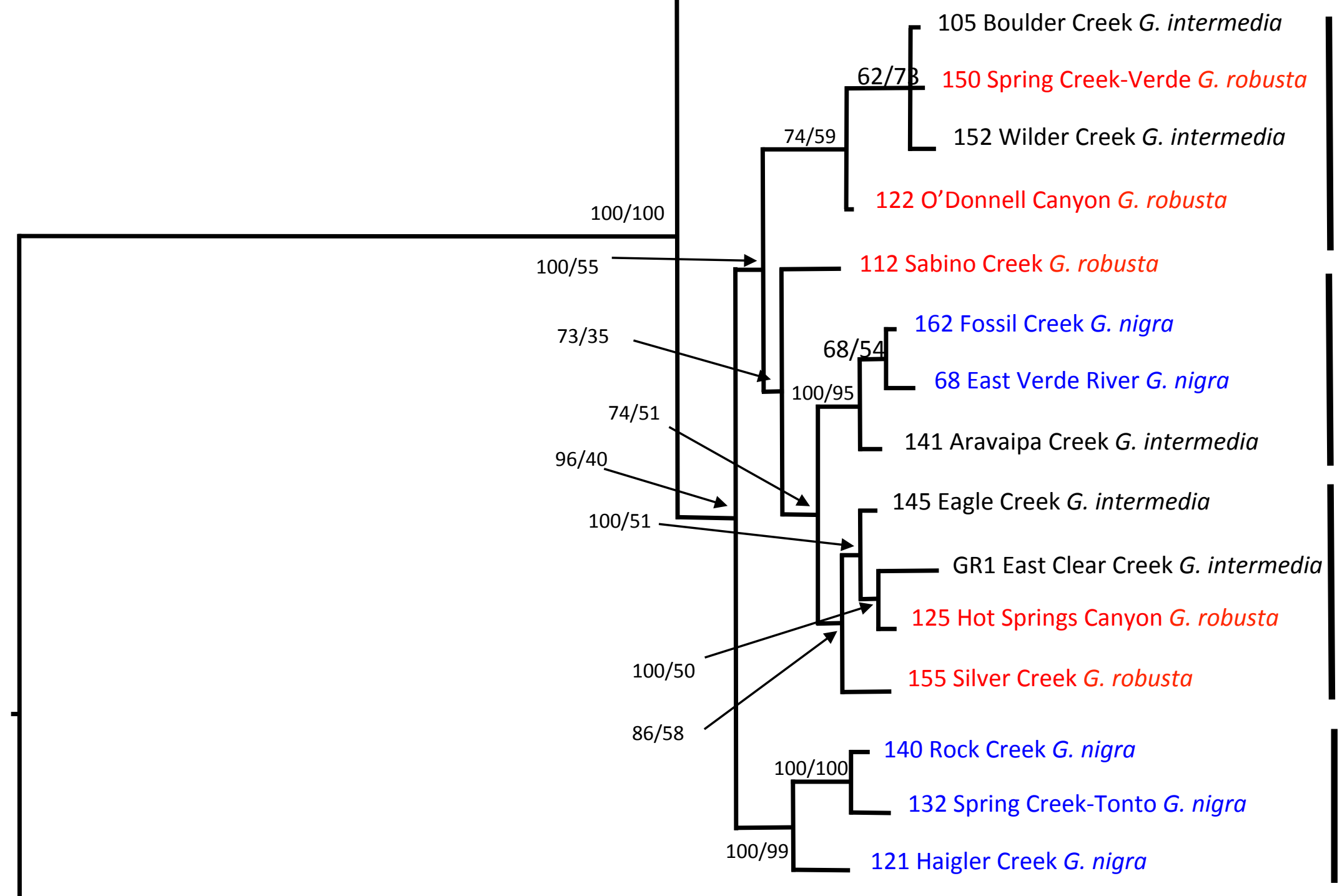

Clade 2

Clade 3

Clade 4

Clade 5 
Figure 4 (on next page)

SNAPP phylogenetic reconstruction

This cloudogram represents the posterior distribution of lineage trees from the Bayesian phylogenetic analysis program SNAPP. Higher density areas indicate greater agreement in tree topologies. Color labels indicate taxonomic assignment of each sample for $G$. robusta (red) G. intermedia (black) and G. nigra (blue). 
140 Rock Creek

112 Sabino Creek

122 O’Donnell Canyon

105 Boulder Creek

152 Wilder Creek

150 Spring Creek-Verde

Clade 2

141 Aravaipa Creek

162 Fossil Creek

68 East Verde River GR1 East Clear Creek

125 Hot Springs Canyon

145 Eagle Creek

Clade 4

Clade 3 


\section{Table $\mathbf{1}$ (on next page)}

Morphometrics and meristics of type material 


\begin{tabular}{|c|c|c|c|c|}
\hline & G. robustra & G. nigra & G. intermedia & G. grahamii \\
\hline & USNM 246 & $\begin{array}{c}\text { USNM 16972, } \\
16987\end{array}$ & USNM 232 & USNM 253 \\
\hline Body depth ${ }^{1}$ & $5.2-5.4$ & 4.1-4.6 & $3.7-4.0$ & 4.5 \\
\hline Head length ${ }^{1}$ & $3.5-3.6$ & $3.5-3.6$ & $3.1-3.4$ & 3.6 \\
\hline Head width ${ }^{3}$ & $1.3-1.4$ & $1.4-1.8$ & $1.4-1.6$ & 1.7 \\
\hline Head depth ${ }^{3}$ & 1.1 & $1.2-1.4$ & $1.3-1.4$ & 1.5 \\
\hline Snout length ${ }^{2}$ & $3.0-3.2$ & $3.0-3.7$ & $3.0-4.0$ & 3.5 \\
\hline Mandible length & $2.1-2.2$ & $2.4-2.9$ & $2.3-2.7$ & 2.5 \\
\hline Orbit diameter $^{2}$ & $5.5-8.1$ & $4.0-6.3$ & $3.6-5.3$ & 2.9 \\
\hline Interorbital width ${ }^{2}$ & $3.1-3.2$ & $3.0-3.9$ & $3.2-3.3$ & 3.1 \\
\hline Upper-jaw length ${ }^{2}$ & $2.5-2.9$ & $3.1-3.5$ & $2.4-4.0$ & - \\
\hline Caudal-peduncle depth ${ }^{3}$ & $2.3-2.6$ & $2.2-2.7$ & $2.3-2.7$ & 2.9 \\
\hline Caudal peduncle length ${ }^{1}$ & $2.9-4.0$ & $4.5-5.2$ & $4.9-6.1$ & 4.6 \\
\hline Predorsal length ${ }^{1}$ & $1.8-1.9$ & $1.7-1.8$ & $1.7-1.8$ & 2 \\
\hline Preanal length ${ }^{1}$ & $1.5-1.6$ & $1.4-1.5$ & $1.4-1.5$ & 1.4 \\
\hline Pectoral insertion to pelvic insertion ${ }^{1}$ & $4.0-4.5$ & $3.4-4.6$ & $1.8-2.1$ & 3.8 \\
\hline Anal to Caudal length ${ }^{1}$ & 3.0-3.1 & 2.9-3.7 & 3.3-3.9 & 3.4 \\
\hline Origin of anal fin to hypural plate ${ }^{1}$ & $2.7-3.0$ & $3.1-3.3$ & $3.0-3.2$ & 3.2 \\
\hline Prepelvic length $^{1}$ & $1.9-2.2$ & $1.8-2.0$ & $1.5-1.9$ & 1.9 \\
\hline Pectoral-fin length ${ }^{1}$ & 3.9-5.7 & $4.8-6.4$ & $4.5-6.8$ & 5.3 \\
\hline Anal fin height ${ }^{1}$ & $4.9-7.4$ & $6.1-7.0$ & $4.9-4.9$ & 5.8 \\
\hline Pelvic-fin height ${ }^{1}$ & 5.5 & $5.8-7.9$ & $5.7-6.9$ & 6.6 \\
\hline Dorsal fin height ${ }^{1}$ & 4.4.6.0 & $4.5-6.1$ & $4.1-5.8$ & 5 \\
\hline Caudal peduncle length/depth & $1.1-1.7$ & $1.9-2.4$ & $1.9-2.4$ & 1.6 \\
\hline Head length/caudal peduncle depth & $1.3-1.5$ & $2.8-2.1$ & $1.2-1.5$ & 1.2 \\
\hline Dorsal rays & 1,9 & 1,8 & 1,8 & 1,9 \\
\hline Anal rays & 1,9 & I,8 & $\mathrm{I}, 8$ & 1,9 \\
\hline Pectoral rays & $13-15$ & $14-15$ & $13-14$ & 14 \\
\hline Pelvic rays & 1,9 & $1,8-9$ & 1,9 & 1,9 \\
\hline Principal caudal rays & $19-23$ & $19-22$ & $23-25$ & 23 \\
\hline Upper procurrent caudal rays & 8 & $7-9$ & 7 & 6 \\
\hline Lateral line scales & $89-92$ & $73-93$ & $59-71$ & 92 \\
\hline Scales above lateral line & $21-23$ & $18-23$ & $16-18$ & 25 \\
\hline Scales below lateral line & 14 & $12-16$ & $11-13$ & 17 \\
\hline
\end{tabular}


Table 2 (on next page)

Morphometrics and meristics of fresh material 


\begin{tabular}{|c|c|c|c|}
\hline & G. robusta & G. nigra & G. intermedia \\
\hline Greatest Body depth ${ }^{1}$ & $3.9-5.3$ & $3.7-5.0$ & $3.9-4.8$ \\
\hline Head length ${ }^{1}$ & $3.4-3.9$ & $3.3-3.8$ & $3.5-3.8$ \\
\hline Head width ${ }^{3}$ & $1.5-2.1$ & $1.6-2.0$ & $1.4-2.1$ \\
\hline Head depth ${ }^{3}$ & $1.1-1.6$ & $1.3-1.6$ & $1.2-1.6$ \\
\hline Snout length ${ }^{2}$ & $3.2-3.8$ & $3.1-3.6$ & $3.0-4.0$ \\
\hline Mandible length ${ }^{2}$ & $2.5-2.8$ & $2.3-2.8$ & $2.4-2.6$ \\
\hline Orbit diameter ${ }^{2}$ & $3.1-4.9$ & $4.4-6.1$ & $3.8-6.0$ \\
\hline Interorbital width ${ }^{2}$ & 3.3-3.9 & 3.1-3.6 & $3.0-3.8$ \\
\hline Upper-jaw length ${ }^{2}$ & $3.0-3.3$ & $1.5-3.4$ & $2.5-3.2$ \\
\hline Caudal-peduncle depth ${ }^{3}$ & 2.1-3.1 & $2.3-2.8$ & 2.3-3.2 \\
\hline Caudal peduncle length ${ }^{1}$ & $5.0-5.7$ & 4.1-4.9 & $4.5-6.1$ \\
\hline Predorsal length ${ }^{1}$ & $1.8-2.0$ & $1.8-2.0$ & $1.8-2.0$ \\
\hline Preanal length ${ }^{1}$ & $1.4-1.6$ & $1.4-1.5$ & $1.4-1.6$ \\
\hline Pectoral insertion to pelvic insertion ${ }^{1}$ & $3.6-4.0$ & $3.5-4.0$ & $3.3-4.0$ \\
\hline Anal to Caudal length ${ }^{1}$ & 2.9-4.2 & $3.0-3.5$ & $3.1-3.8$ \\
\hline Origin of anal fin to hypural plate ${ }^{1}$ & 2.9-3.6 & $2.9-4.8$ & $3.0-4.0$ \\
\hline Prepelvic length ${ }^{1}$ & $1.8-2.1$ & $1.9-3.5$ & $1.9-2.0$ \\
\hline Caudal-fin length ${ }^{1}$ & $3.5-4.2$ & $3.9-5.2$ & $3.9-4.6$ \\
\hline Caudal concavity ${ }^{2}$ & $1.8-3.0$ & $2.6-3.5$ & $2.1-3.0$ \\
\hline Pectoral-fin length ${ }^{1}$ & $5.3-7.2$ & $5.2-6.4$ & $5.5-8.5$ \\
\hline Anal fin length ${ }^{1}$ & $5.5-6.7$ & $5.7-6.6$ & $5.6-7.8$ \\
\hline Pelvic-fin length ${ }^{1}$ & $6.7-7.8$ & $6.3-7.7$ & $6.5-8.8$ \\
\hline Dorsal fin length ${ }^{1}$ & $4.4-5.4$ & $4.5-5.5$ & $4.6-6.6$ \\
\hline Caudal fin length ${ }^{1}$ & $4.0-4.7$ & $4.4-6.1$ & $4.3-5.2$ \\
\hline Caudal peduncle length/depth & $1.6-2.5$ & $1.5-2.1$ & $1.5-2.6$ \\
\hline Head length/caudal peduncle depth & $1.2-1.7$ & $1.2-1.7$ & $1.2-1.5$ \\
\hline Dorsal rays & $1,8-9$ & $1,8-9$ & ।,8-9 \\
\hline Anal rays & $1,8-9$ & ।,8-9 & ।,8-9 \\
\hline Pectoral rays & $14-16$ & $14-16$ & $13-15$ \\
\hline Pelvic rays & 1,9 & 1,9 & 1,9 \\
\hline Principal caudal rays & 19 & 19 & 19 \\
\hline Upper procurrent caudal rays & $8-10$ & $6-11$ & $7-10$ \\
\hline Lateral line scales & $82-95$ & $82-89$ & $65-87$ \\
\hline Scales above lateral line & $23-26$ & $20-23$ & $17-21$ \\
\hline Scales below lateral line & $11-15$ & $11-15$ & $10-14$ \\
\hline Gill rakers & $7-8,2$ & $6-7,2$ & $7-9,2$ \\
\hline
\end{tabular}




\section{Table 3 (on next page)}

Assignment of samples to type material 


\begin{tabular}{|c|c|c|c|c|c|c|c|c|c|c|c|c|c|c|c|c|c|c|}
\hline Types & \multicolumn{6}{|c|}{ G. robusta } & \multicolumn{5}{|c|}{ G. nigra } & \multicolumn{7}{|c|}{ G. intermedia } \\
\hline & 105 & 133 & 141 & 145 & 152 & GR1 & 68 & 121 & 132 & 140 & 162 & 100 & 112 & 122 & 125 & 150 & 155 & Avera \\
\hline G. robusta & 0.22 & 0.22 & 0.26 & 0.35 & 0.26 & 0.39 & 0.35 & 0.35 & 0.30 & 0.35 & 0.22 & 0.22 & 0.26 & 0.22 & 0.35 & 0.30 & 0.30 & 0.29 \\
\hline G. nigra & 0.57 & 0.65 & 0.70 & 0.61 & 0.61 & 0.65 & 0.65 & 0.70 & 0.70 & 0.65 & 0.57 & 0.65 & 0.65 & 0.57 & 0.78 & 0.26 & 0.35 & 0.61 \\
\hline G. intermedia & 0.52 & 0.57 & 0.57 & 0.39 & 0.57 & 0.48 & 0.43 & 0.52 & 0.48 & 0.43 & 0.57 & 0.39 & 0.65 & 0.43 & 0.43 & 0.48 & 0.39 & 0.49 \\
\hline unclassified & 0.17 & 0.26 & 0.13 & 0.22 & 0.17 & 0.09 & 0.13 & 0.09 & 0.17 & 0.22 & 0.30 & 0.22 & 0.13 & 0.26 & 0.09 & 0.13 & 0.39 & 0.19 \\
\hline
\end{tabular}

1 


\section{Table 4(on next page)}

morphology by plylogenetic clade 


\begin{tabular}{|c|c|c|c|c|c|}
\hline & Clade 1 & Clade 2 & Clade 3 & Clade 4 & Clade 5 \\
\hline Body depth ${ }^{1}$ & $3.7-5.0$ & $3.8-5.2$ & $4.2-4.6$ & $4.0-5.2$ & $3.9-5.3$ \\
\hline Head length ${ }^{1}$ & 3.3-3.8 & $3.7-3.8$ & $3.4-3.6$ & $3.4-3.8$ & $3.4-3.8$ \\
\hline head width ${ }^{4}$ & $1.5-2.0$ & $1.6-2.1$ & $1.6-1.9$ & $1.6-2.1$ & $1.4-2.1$ \\
\hline head depth ${ }^{4}$ & $1.3-1.6$ & $1.3-1.6$ & $1.3-1.4$ & $1.1-1.4$ & $1.2-1.6$ \\
\hline Snout length ${ }^{2}$ & 3.3-3.6 & 3.3-3.7 & $3.1-3.5$ & $3.0-3.8$ & $3.1-4.0$ \\
\hline mandible length ${ }^{2}$ & $2.3-2.7$ & $2.5-2.8$ & $2.4-2.8$ & $2.5-2.8$ & $2.4-2.6$ \\
\hline Orbit diameter ${ }^{2}$ & $4.7-6.1$ & $4-4.1$ & $4.4-4.8$ & $3.7-4.5$ & $3.1-6.0$ \\
\hline Interorbital width ${ }^{2}$ & $3.1-3.5$ & 3.3-3.5 & $3.5-3.6$ & $3.3-3.6$ & $3.0-3.9$ \\
\hline Upper-jaw length ${ }^{2}$ & $2.8-3.4$ & $3.0-3.3$ & $1.5-3.2$ & 3.1-3.2 & $2.5-3.3$ \\
\hline Caudal-peduncle depth ${ }^{4}$ & $2.3-2.8$ & $2.2-3.1$ & $2.4-2.8$ & $2.1-2.8$ & $2.3-3.2$ \\
\hline Caudal peduncle length ${ }^{1}$ & 4.1-5.7 & $4.5-4.9$ & $4.5-4.9$ & $4.8-5.4$ & $4.5-6.1$ \\
\hline Predorsal length ${ }^{1}$ & $1.8-2.0$ & $1.8-2.0$ & $1.8-1.9$ & $1.8-1.9$ & $1.8-2.0$ \\
\hline Preanal length ${ }^{1}$ & 1.5 & 1.5 & $1.4-1.5$ & $1.4-1.6$ & $1.4-1.6$ \\
\hline pectoral insertion to pelvic insertion ${ }^{1}$ & $3.7-3.9$ & 3.7-3.8 & $3.6-4.0$ & 3.5-3.9 & $3.3-4.0$ \\
\hline Anal to Caudal length ${ }^{1}$ & 3.3-3.7 & $3.2-3.4$ & 3.0-3.5 & 3.0-3.4 & $2.9-4.2$ \\
\hline origin of anal fin to hypural plate ${ }^{1}$ & 3.3-3.6 & 3.1-3.4 & $2.9-4.8$ & $3.2-3.6$ & $2.9-4.1$ \\
\hline Prepelvic length ${ }^{1}$ & $1.9-2.1$ & 2 & $1.9-3.5$ & $1.8-2.0$ & $1.9-2.0$ \\
\hline Pectoral-fin length ${ }^{1}$ & $5.8-6.3$ & $4.9-7.2$ & $5.2-6.4$ & $5.4-6.3$ & $5.3-8.5$ \\
\hline Anal fin height ${ }^{1}$ & $1.7-1.9$ & $1.5-1.6$ & $1.6-1.9$ & $1.5-1.7$ & $1.5-2.2$ \\
\hline Pelvic-fin height ${ }^{1}$ & 2 & $1.7-2.0$ & $1.8-2.2$ & $1.8-2.0$ & $1.9-2.5$ \\
\hline Dorsal fin height ${ }^{1}$ & $1.5-1.6$ & 1.4 & $1.3-1.5$ & 1.3 & $1.3-1.9$ \\
\hline caudal peduncle length/depth & $1.5-2.5$ & $1.6-2.0$ & $1.7-1.9$ & $1.8-2.4$ & $1.5-2.6$ \\
\hline head length/caudal peduncle depth & $1.2-1.7$ & $1.3-1.7$ & $1.3-1.5$ & $1.2-1.7$ & $1.2-1.5$ \\
\hline Dorsal rays & 1,8 & $1,8-9$ & 1,9 & $1,8-9$ & $1,8-9$ \\
\hline Anal Rays & $1,8-9$ & $1,8-9$ & $1,8-9$ & $1,8-9$ & 1,8 \\
\hline Pectoral rays & $14-15$ & $14-15$ & $14-16$ & $14-15$ & $13-16$ \\
\hline Principal caudal rays & 19 & 19 & 19 & 19 & 19 \\
\hline Upper procurrent caudal rays & $7-11$ & $9-10$ & $6-11$ & $8-9$ & $7-10$ \\
\hline Lateral line scales & $82-86$ & $85-87$ & $85-89$ & $72-82$ & $65-95$ \\
\hline Scales above lateral line & $20-23$ & $21-26$ & $21-23$ & $18-25$ & $17-24$ \\
\hline Scales below lateral line & $14-15$ & $10-14$ & $11-14$ & $11-15$ & $10-14$ \\
\hline
\end{tabular}

